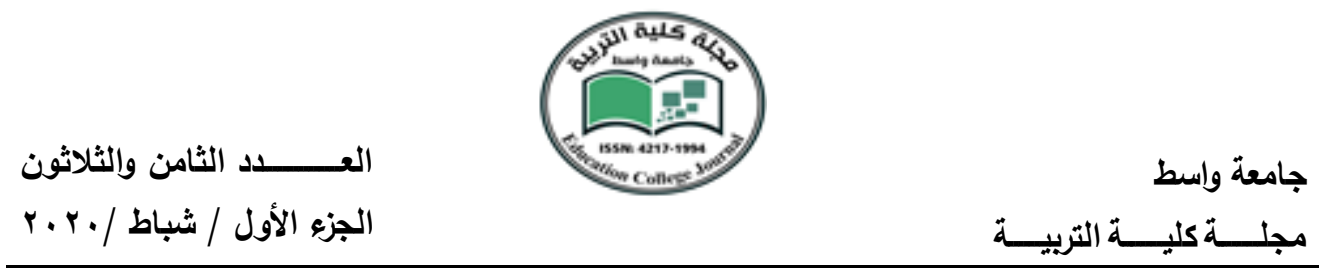

\title{
ذكر القصب في أساطير بلاد الراقدين
}
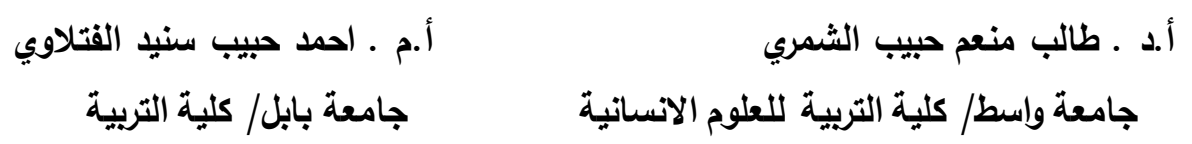

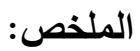

تتاول البحث ذكر القصب في اساطير بلاد الرافدين ويتالف البحث من خمسة محاور اهنت

المحور الاول: بخلق القصب في الاساطير وفي المحور الثاني: القصب ودوره في عمليات الخلق. أما في المحور الثالث فقد تتاول استعمالات القصب في ضوء ما ورد في الاساطير، وفيه نم التطرق ودي ودي الى استعمال القصب في صنع الأسلحة ونشيد حظائر الآلهة من القصب واستخدام القصب في بناء سفن وزوارق الالهة وتقديم القصب في الهايا وتتاول القصب طعاماً في مآدب الآلهة واستعمال القصب في بناء بيوت الآلهة (المعابد)، وبيوت البشر، وفي صنع اثاث الالهة ، وفي اقامة السدود لتجفيف أراضي الاهوار واصطصلاحها، وحرفة عامل القصب، وتطرق المحور الرابع الى الاخطار التي تهدد حقول القصب بالدمار في ضوء الاساطير وفي المحور الخامس تطرقنا الى دور الالهة في تحقيق البركة والخصب في حقول القصب.

\section{Abstract:}

The research discussed the reeds in the legends of Mesopotamia. The research consists of five axes. In the first axis, we discussed the creation of reeds in the legends and in the second axis, reeds and its role in the processes of creation. In the third axis, we dealt with the uses of cane in the light of the myths mentioned in the use of reeds in the manufacture of weapons and the building of God's sheds of cane and the use of cane in the construction of vessels and boats of Goddess and to provide reeds in gifts and eat reeds as food in Madaba Goddess and the use of canes in building houses of Goddesses (Temples) and houses of humans and the use of cane in the manufacture of furniture Goddess and the use of reeds in the establishment of dams to dry the lands of the marshes and their reclamation and the cane worker. In the fourth axis we dealt with the dangers that threaten the fields of cane destruction in light of the myths and in the fifth axis dealt with the role of God in the realization of blessing and fertility in the cane fields. 
العـــــــــد الثامن والثثلاثون

الجزء الأول / شباط /.r.r.

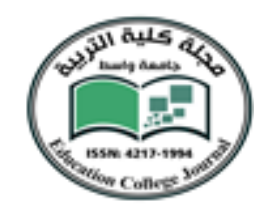

جامعة واسط

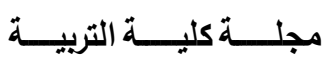

المقدمة:

لم تقتصر فائدة القصب على استخداماته المتعددة في الحياة اليومية عند سكان بلاد الرافدين،

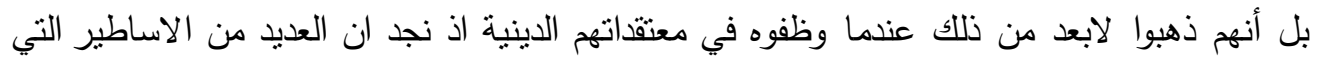
تتتاول بين مضامينها الخلق وعلاقات الآلهة ببعضها، قد ذكرت معلومات فئونات وشروح متباينة عن الكيفية التي وظف فيها القصب في هذه الاساطير وتبيان دوره في عملية خلق الكون واستخداماته المتعدة

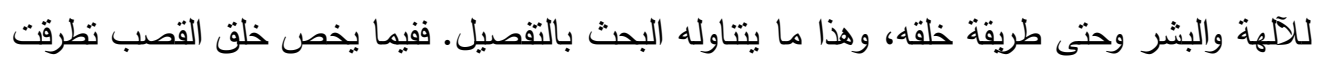

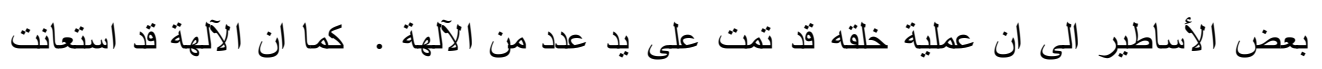

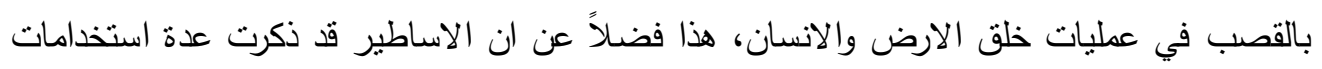

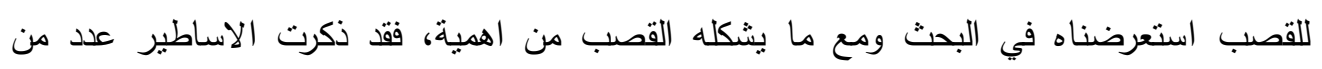

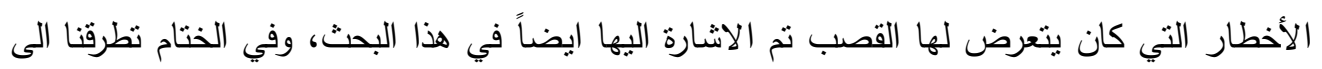

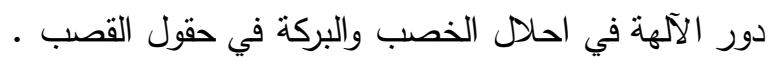

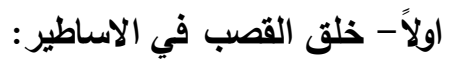

يعد القصب من الموجودات التي أوجدتها الآلهة، وقد نتوعت عقائد سكان بلاد الرافدين في بيان من

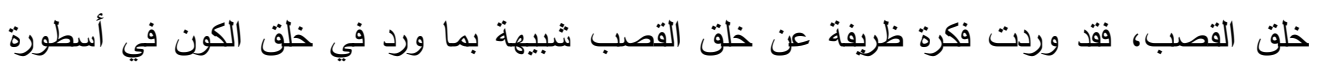

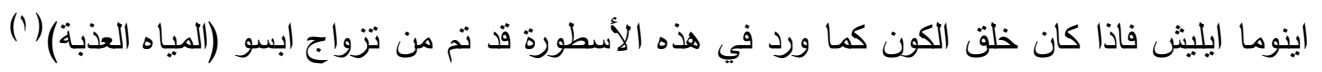

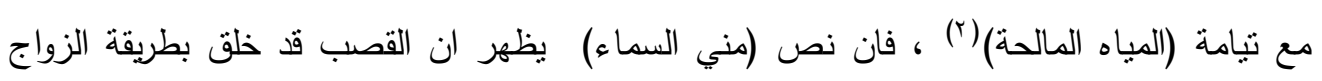

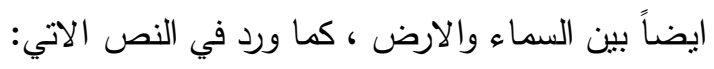

"الأرض الفسيحة المسطحة لبست تألقها ، جملت بيهجةٍ جسدها.الارض العريضة ،

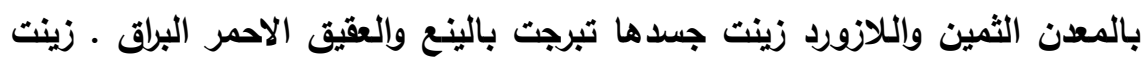

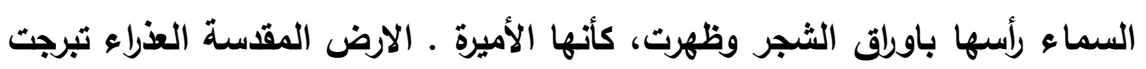

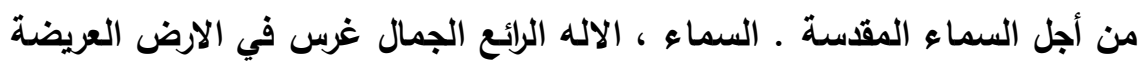

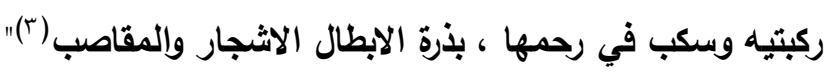
نستتج من النص اعلاه ان عملية خلق القصب تثبه عملية الجماع عند الانسان. 
العــــــــد الثامن والثلاثون

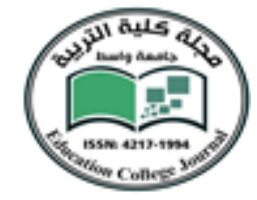

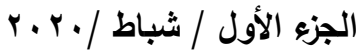

جامعة واسط

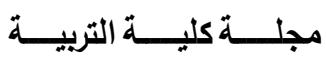

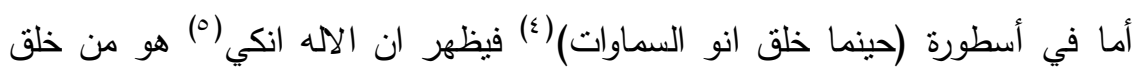

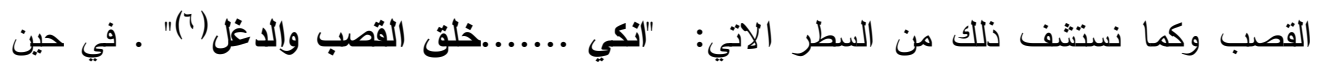
يظهر الاله مردوك في اسطورة اريدو هو الذي قام بخلق كل من القصب والبردي والهور، وتقصد هنا

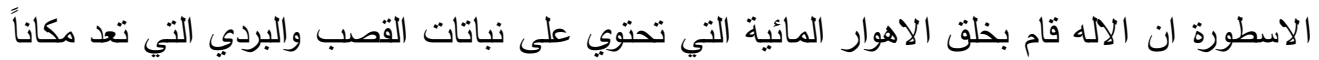
ملائماً لنموهما بكثافة اذ ورد ما نصده:

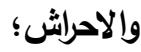
الاهوار، والقصب، مردوك).........بردي "خلق اي

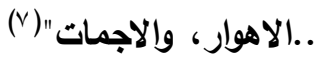

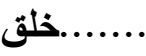

اما عن خلق الاهوار التي تعد كما اسلفنا سابقاً بيئة مناسبة لنمو القصب والبردي فيتضح مما ورد في

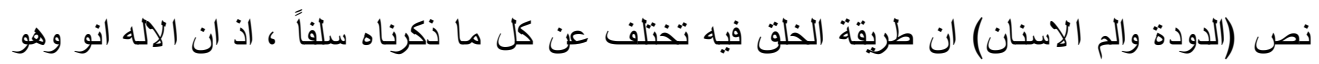

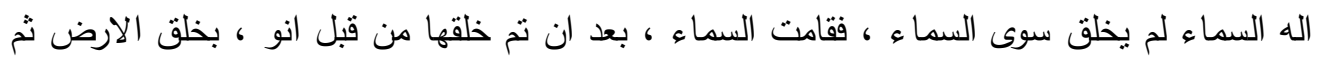

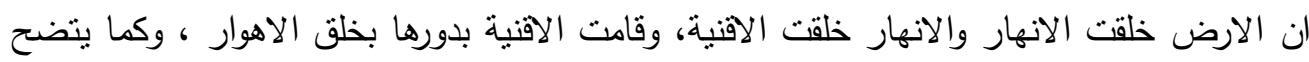

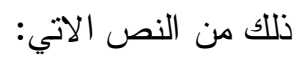

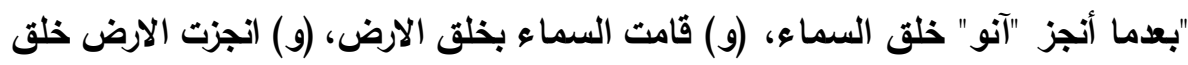

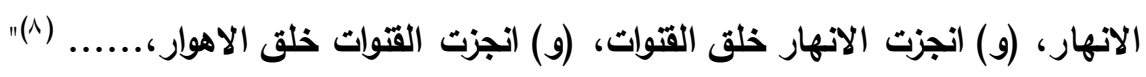

نستتنج مما ورد في النص أعلاه ان سكان بلاد الرافدين قد لاحظوا كيفية تكون الاهوار في بيئتهم

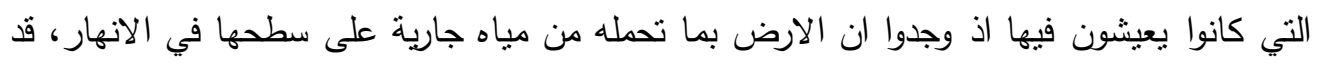

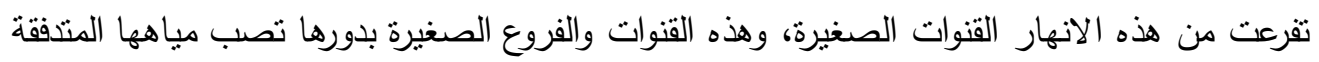

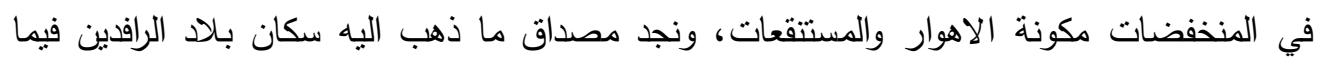

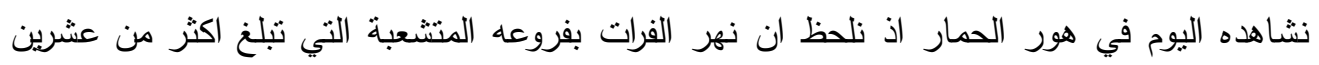

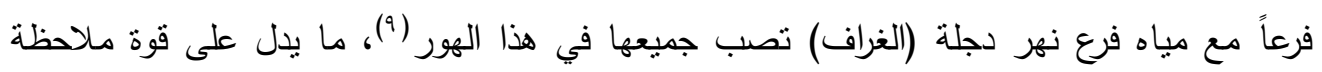

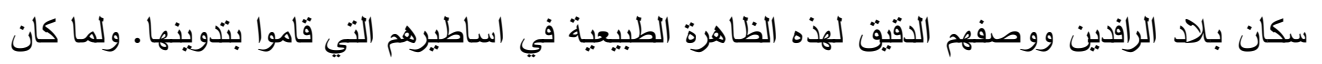

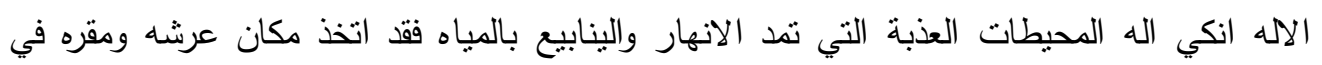

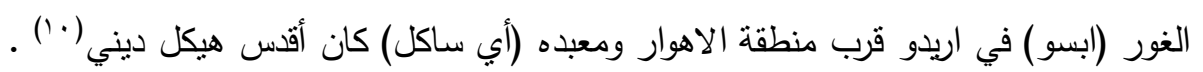


العـــــــــد الثامن والثلاثون

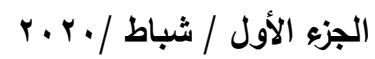

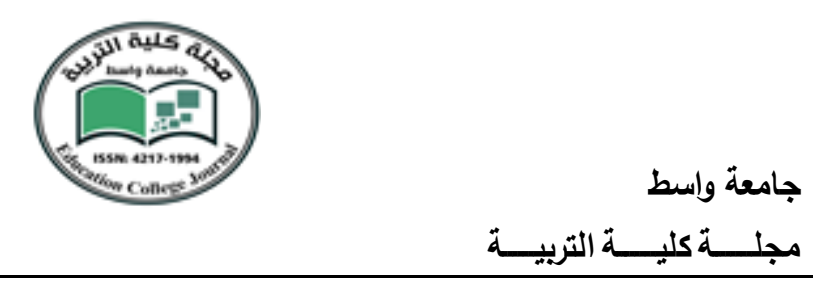

ثانياً - القصب ودوره في عمليات الخلق : كابن

كان للقصب دور كبير في خلق العالم بحسب ما ورد ذلك في اسطورة (اريدو)(' ')، نسبة الى مدينة

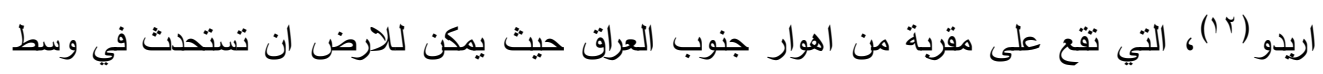

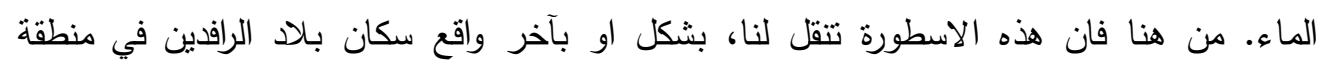

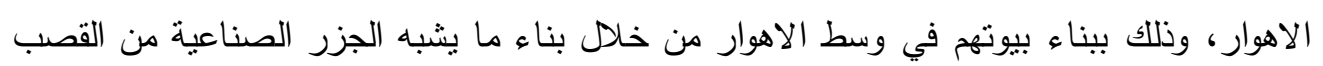

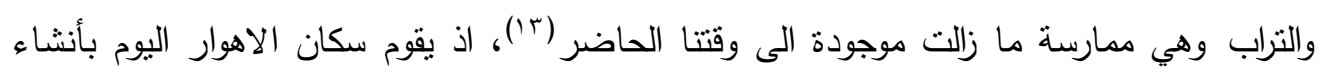

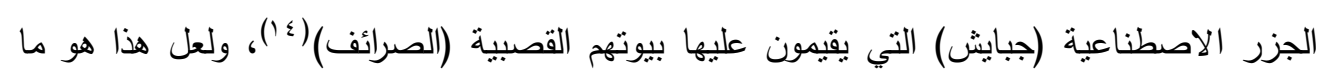

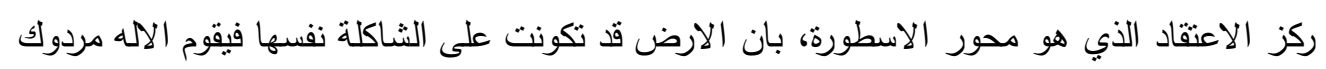

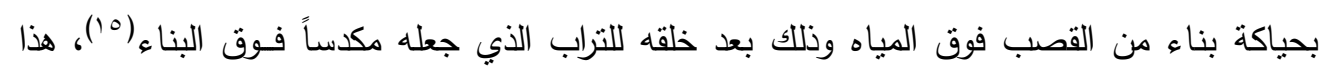

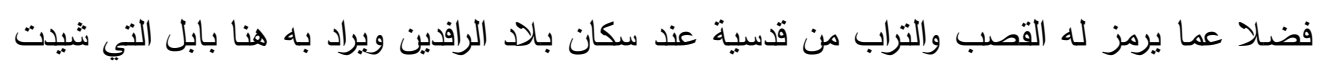

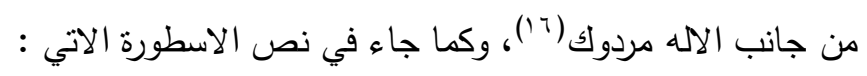

$$
\begin{aligned}
& \text { " وشيد ايساكيلا ....حيث بابل انش(أت).... وانشأ مردوك اطاراً من القصب على سطح }
\end{aligned}
$$

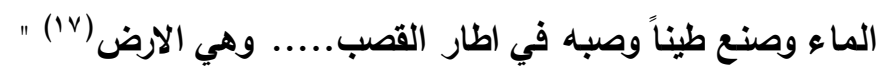

وبعد ان خلق مردوك الارض بالطريقة التي تصنع فيها الجزر في وسط الاهوار (^)، قام بخلق نهري

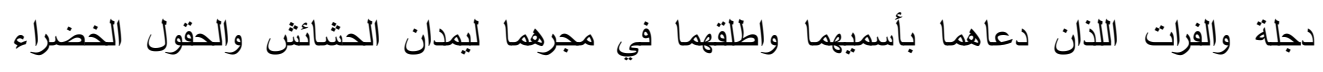

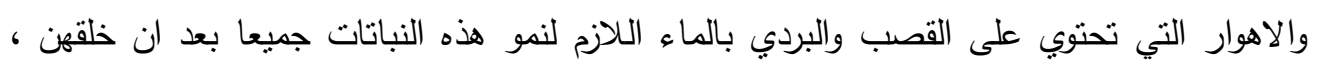

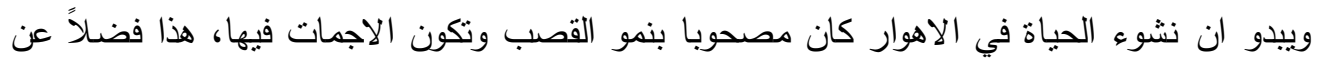

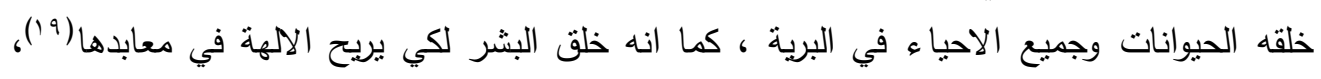
وكما يتبين ذللك في النص الاتي:

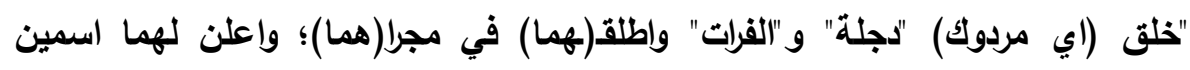

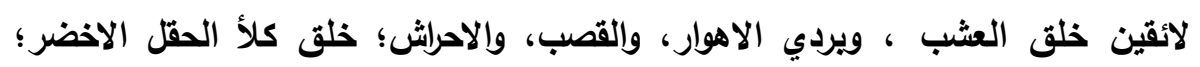

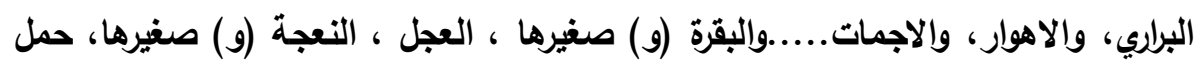

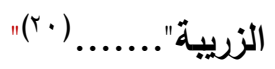


العــــــــد الثامن والثلاثون

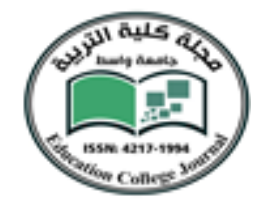

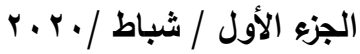

جامعة واسط

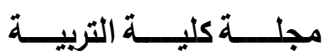

واذا كان القصب بحسب ما ورد في اسطورة اريدو يعد احد المادتان الرئيسيتان الداخلة في خلق

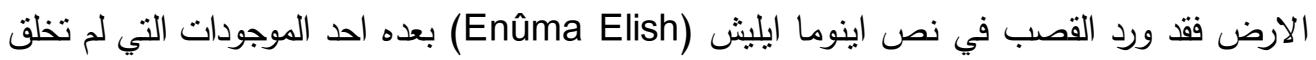

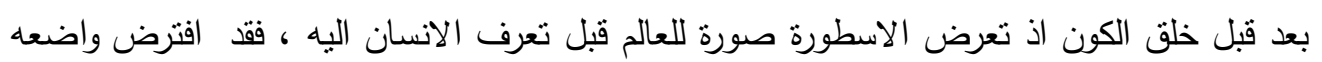

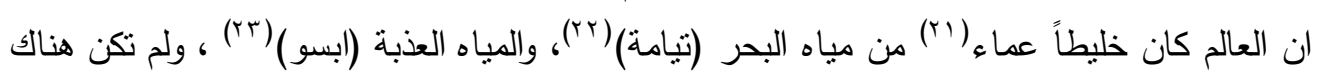

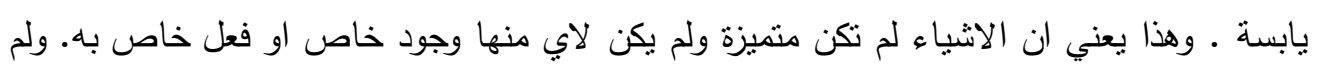

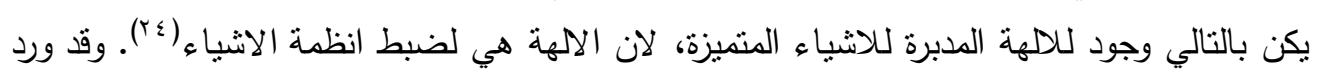

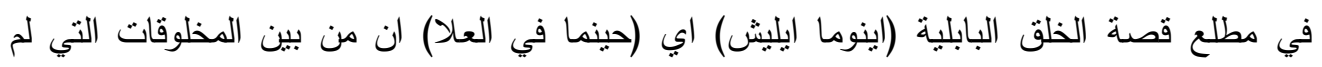

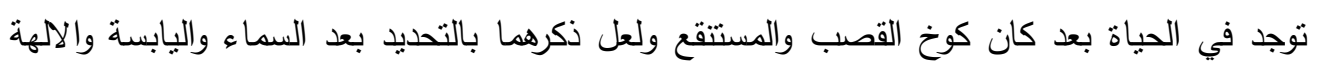
دون سواهما من المخلوقات الاخرى ما يبين لنا ان الحضارة اول ما وجدت كانت في الاهوار حيث

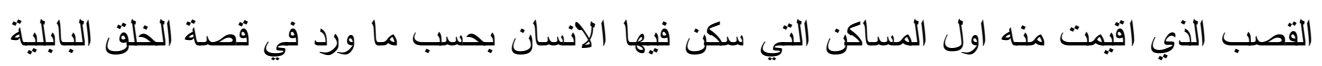

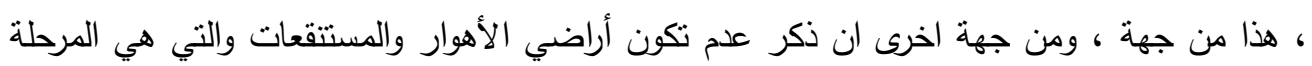

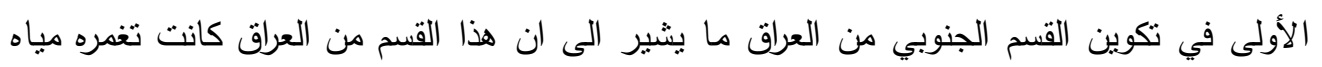

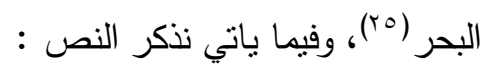

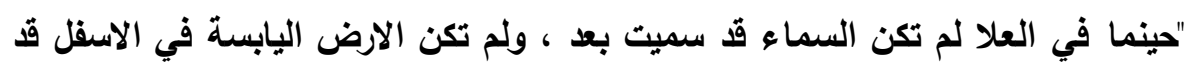

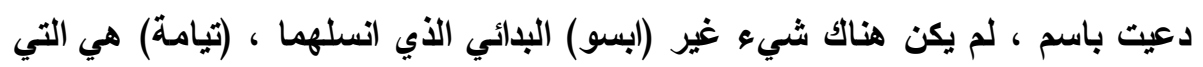

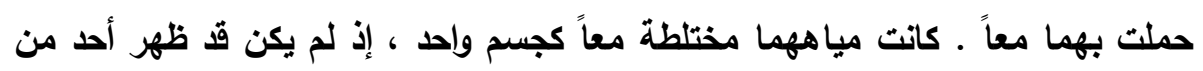

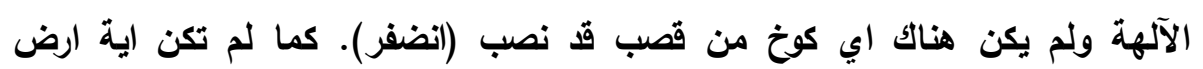

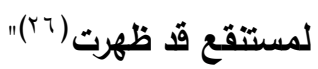

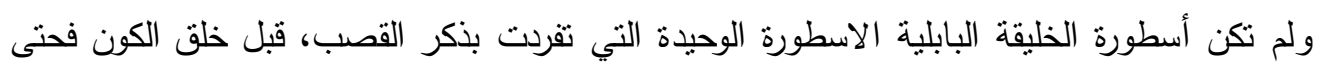

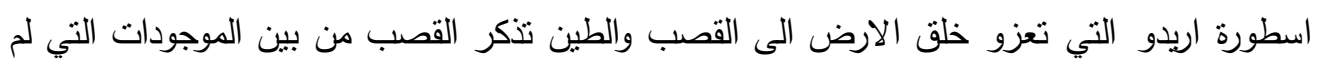

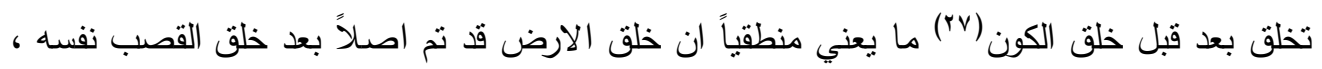
وكما نستتنج ذلك من مقدمة نص الاسطورة الاتي :

"ما من بيت مقد، ولا بيت الَهة،، كان (بعد) قد شيد في الموضع المقس؛ لم يكن ثمة

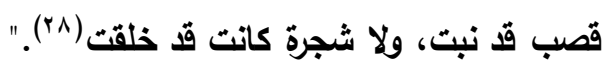


العـــــــــد الثامن والثلاثون

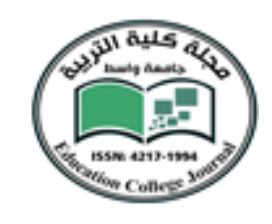

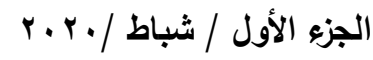

جامعة واسط

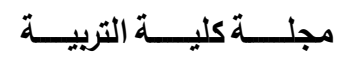

ان ورد ذكر القصب في الاسطورتيين الانفتين الذكر يدل دلالة واضحة على اهميته في نظر سكان بلاد الرافدين لدرجة ان الاسطورتان قد استشهتا به ككائن حي لم يخلق بعد قبل خلق المخلوقات

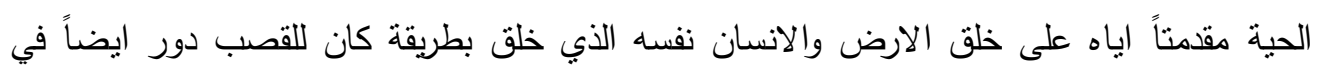
خلقه اذ نقرأ في قصة خليقة بابلية عن خلق مردوك للانسان بوضعه طيناً في قصبة، وخلق الانسان

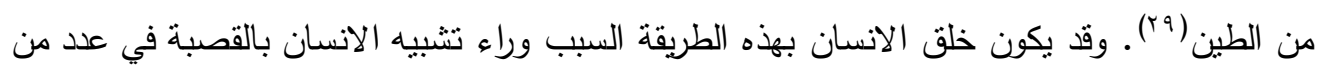
النصوص المسمارية والتي تطرقنا لها في عدد من المباحث في الفصل الرابع.

واتماماً للفوائد التي يمنلها القصب عند سكان بلاد الرافدين فيما يتعلق بخلق الانسان فقد ورد في احد النصوص البابلية التي تنتعرض خلق الانسان على بد الالهة مامي باشراف الاله انكي استعماله

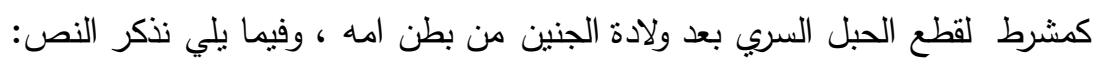

"وعدما أنهت تعويذتها، قبضت أربع عشر قبصةً (من الطين)، (ووضِعت) سبع قطع منها

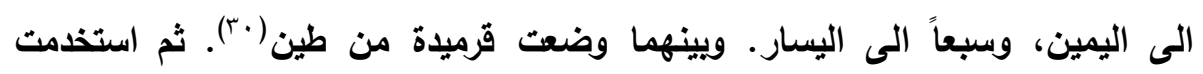
فتحتها لتقطع الحبل السري ودعت الههات الرحم الحكيمات ( آب)"

وطالما اننا ما زلنا في موضوع الحمل والولادة فقد استعملت مفردة القصبة في احد

النصوص تعبيراً مجازياً عن المدة الزمنية(rr) التي يستغرقها الجنين للخروج من بطن امه في اثناء الولادة، وكما مبين في النص الاتي:

" وعند حلول الشهز العاشر، انسلت في قصبة وشقت الرحم. بدا وجُهها مسروراً وفرِحاً. غطت رأسها، وقامت بعمل القابلة (rr)"

ثالثاً -استخدامات القصب في ضوء ما ورد في الاساطير: يستذل مما ورد في الاساطير الرافدينية ان هناك استخدامات عديدة للقصب نم الاشارة اليها في اكثر من اسطورة ما يدل على اهميته للآلهة والبشر على حد سواء فقد استعرضت الاساطير الاستخدامات المتتوعة للقصب منل تناوله طعاماً وتقديمه هدايا في مناسبات معينة كما تم التطرق في هذه هينه 
العــــــــــد الثامن والثلاثون

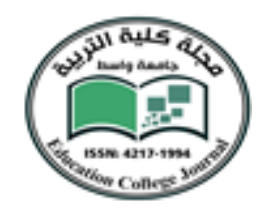

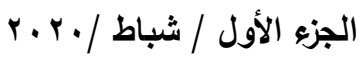

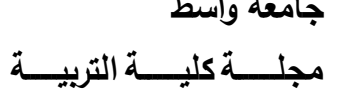

الاساطير الى كيفية الاستفادة منه في صنع اسلحة الالهة وبناء القوارب والمعابد وغيرها من الاستخدامات الاخرى التي سوف نتناولها بالتفصيل فيما ياتي:

أ-استخدام القصب في صنع الاسلحة:

كان من الاستخدامات المهمة للقصب والتي اشارت اليها الاساطير استخدامه في صنع اسلحتها الفتاكة فقد صنعت الالهة من القصب سهامها القاتلة التي كانت تصوبها باتجاه اعدائها في معاركها الدامية التي تخوضها مسببتاً لاعدائها الجراح البليغة، بحسب ما ورد ذلك في أسطورة (انزو (Anzu)

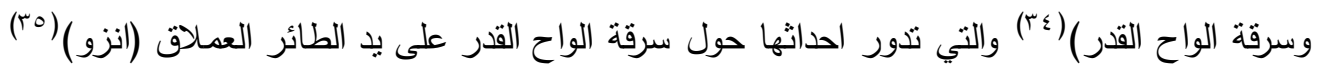
(Anzu) من كبير الآلهة (انليل) (Enlil) اذ يظهر من مضمون النص ان انزو قد خطط، عن قصد وعمد لسرقة الواح القدر والاستيلاء على السلطة(rr) وقد نجح في اختطاف نلك الالواح من الإله

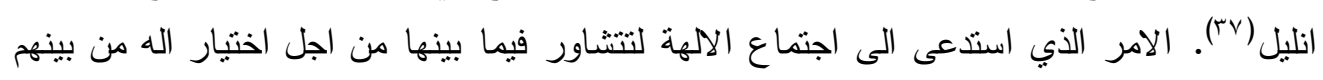
يقوم بمهمة استرداد الواح القدر من الطائر العملاق انزو وفي كل مرة كان يقع فيها اختيار الاله انو على اله(^^) كان يرفض تنفيذ هذه المهمة ؛ بسبب امتلاك انزو لالواح القدر والتي يظهر انها اعطته

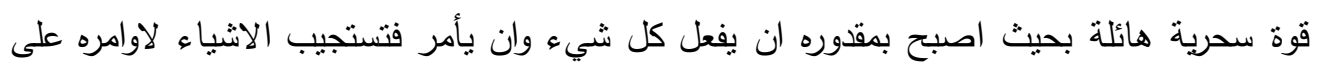

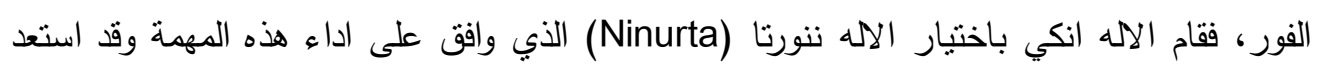
لمعركته المصيرية مع غريمه الطائر انزو بان حمل قوسه المصنوع من خشب الغابة وسهامه المصنوعة من قصب الهور وتقدم لمنازلة الطائر انزو عند منحدر الجبل(جّ) هن اجل استرداد الواح القدر منه، وفي المعركة صوب ننورنا احد سهامه القصبية باتجاه انزو الا ان سهام ننورتا القاتلة هذه وققت عاجزة امام الطائر العملاق انزو المتسلح باللواح القدر فقد امر السهم القادم باتجاهه بان يعود بادياه الى القصب الذي اخذ منه وكما هو واضح في النص الاتي:

"مد قوسه وسلحه بقصبة (سهم)، ومن عارضة القوس، رشق انزو بالسهم (القصبة)

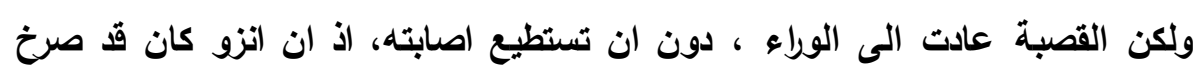

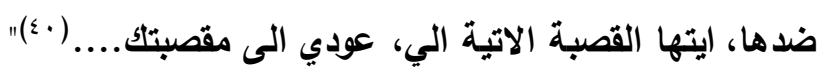

وكذللك الحال مع القوس اذ عاد خشب القوس ذاته الى غابته، واوتار القوس الى مصران الخروف الذي صنعت منه(اء) ما يعني ان الاله ننورتا قد جرد من سلاحه وهنا توقف القتال "وخيم على 
العــــــــــد الثامن والثلاثون

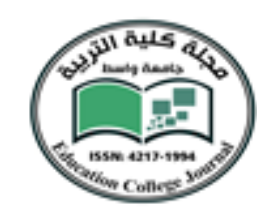

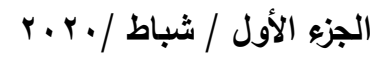

جامعة واسط

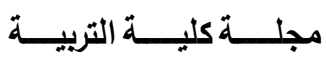

المعركة صمت مميث"(؟؟)، على حد قول النص، فايقن ننورتا ان سهام القصب لم تعد تجدي نفعاً امام انزو الماسك باللواح القدر فارسل رسوله (شارو) الى انكي ليخبره بما جرى ويطلب منه النصيحة(r٪) ، فيسدي النصح لرسوله ويطلب انكي من ننورتا ان يتابع القتال دون كلل. ولان الطائر العملاق انزو يرد سهام القصب بكلماته وهذا يعني ان الكلمة مع امتلاك الواح القدر كانت ذات منطق عملي محدد بطبائع الاشياء ، وليس بسحر خرافي(؟) ، فيتوجب على ننورتا ان يلهيه عن

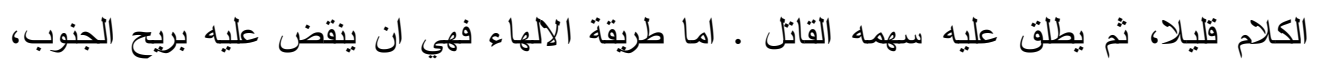
فينفش له ريش قوادم جناحيه، ثم ينتزع هذه الرياش بسلاح العاصفة نفسها. ولا يستطيع انزو الحؤول

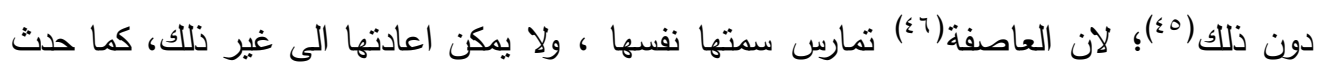
لسهم القصب والقوس. يصرخ عندئذ انزو لما حدث له. واثناء صراخه وذهوله للمفاجأة ينسى ان يأمر

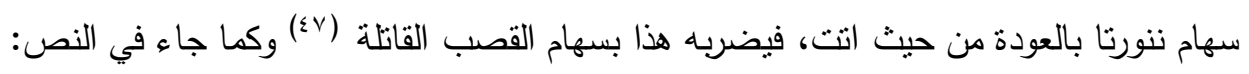
"لا تلع القتال يضعف ، واصل الضغط بشدة حتى النصر انهكه حتى ينسل ريشه في مواجهة العواصف واتبع سهامك بضربة من هراوتك قص جناحيه ، وافصل الايمن منهما عن الايسر وعذدما يرى ما حل بجناحيه ويصرخ (جناحي ! جناحي!) فاياك ان ترتعب ؛

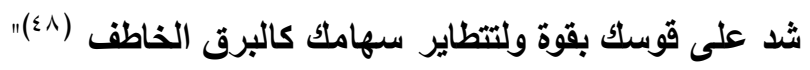

فعاد الرسول شارور الى سيده ننورتا حاملا رسالة اله الحكمة انكي بما يجب فعله للقضاء على انزو • واتبع ننورتا وصايا الاله انكي في اخر جولة من النزال مع الطائر الشرير انزو فاعد العدة جيدا في نزاله السابع معه اذ استعان بالرباح التي "حشدها كلها في تتظيم قتالي"(9ء) وتشلح بقوسه المصنوع من خشب الغابة وسهامه المصنوعة من القصب وعندما وقعت المعركة ابتل كلا المقاتلين بالعرق من بن شدة القتال الا ان الاعياء بدى واضحاً اكثر على انزو الذي انسل وتطاير ريش جناحيه في مواجهة العاصفة التي كانت احد اسلحة ننورتا وهنا استغل ننورتا الموقف فصوب احد سهامه نحو قلبه واخر باتجاه جناحيه ورئتيه ليقضي بذلك عليه ويعود بالواح القدر وتعود السلطة الى المعبد ايكور وعن ذلك

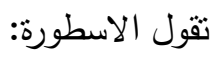
"(بتل كلاهما بعرق المعركة واصبح انزو منهكاً وكان ريش جناحيه ينسل ويتطاير (•) في مواجهة العواصف فاخترق سهم وسط قلبه ثم اتبعه نتورتا بسهم خرق قوادمه وجناحيه 
العـــــــــد الثامن والثلاثون

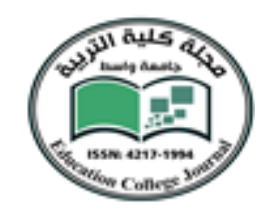

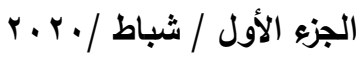

جامعة واسط

مجلـــــة كليــــــة التربيـــــة

واخترق سهم اخر قلبه ورئتيه ...وذبح انزو ثم استعاد المقاتل نتورتا الواح القدر

بيده( (0)

وهكذا نستشف من النص اعلاه ان القوس والسهام المصنوعة من القصب كانت من الاسلحة الفتاكة

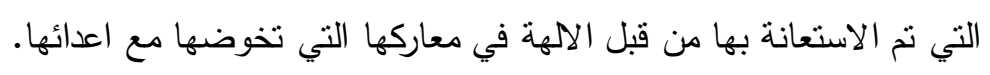

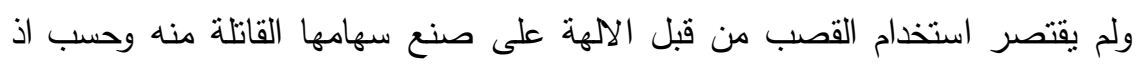

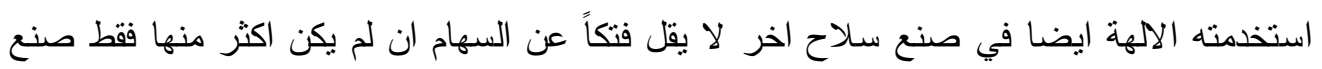

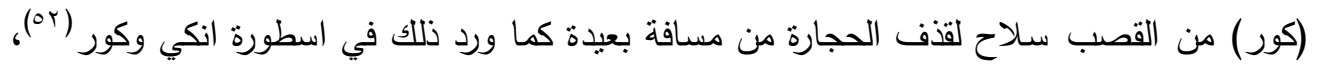

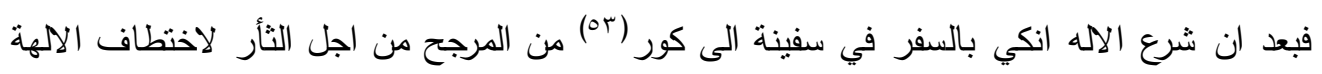
(ارشكيكال Ereshkigal) على يد الوحش كور الذي حملها الى العالم الاسفل فان الاخير اخذ يقاتل

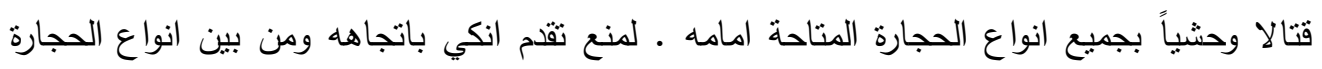

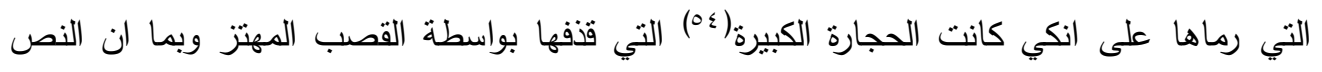

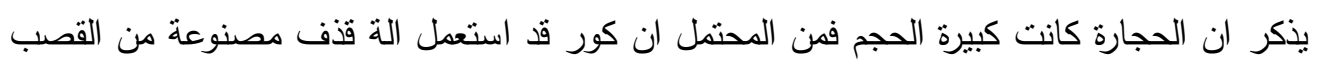

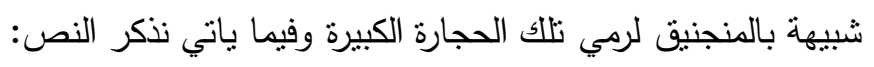

"بعد ان ابحر انكي ، ليقاتل كور (00)، ابحر الى العالم السفلي، ابحر الى عالم الرنيلة، العبا.

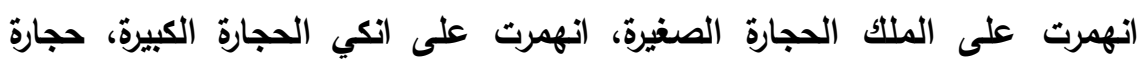

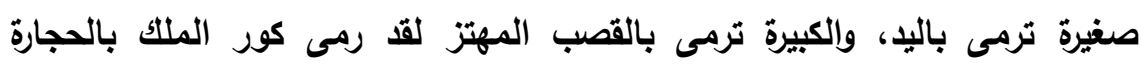

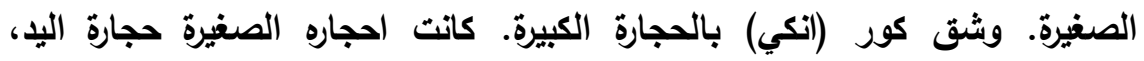

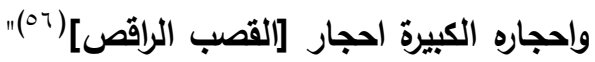

كما كان يصنع من القصب حبال متينة استخدت في شد وثاق الالهة فبعد قيام شياطين الكالا

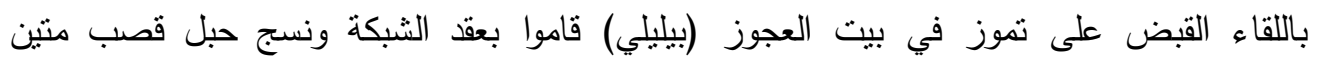

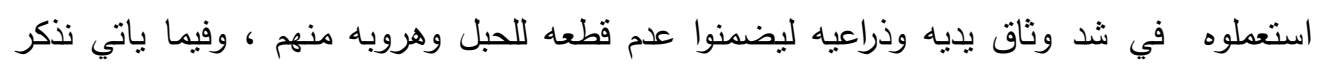
النص: 
العـــــــــد الثامن والثلاثون

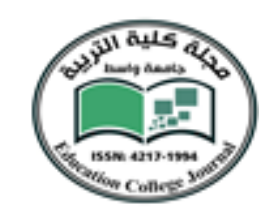

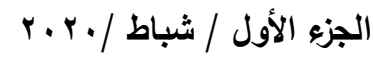

جامعة واسط

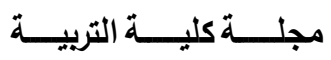

"هيا دعونا نذهب الى بيت العجوز بيليلي قبضوا على دموزي في منزل السيدة العجوز

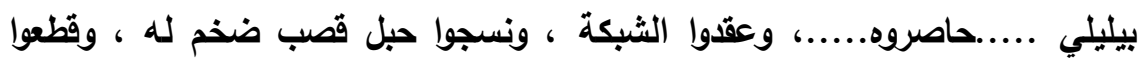

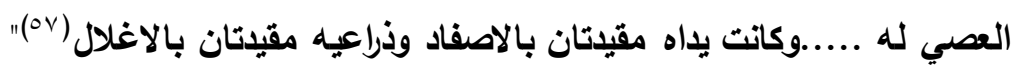

وييدو ان الحبل كان قوي جداً فلم يسنطيع تموز ان بقطعه ؛ لهذا السبب فقد استتجد تموز بالاله اوتو

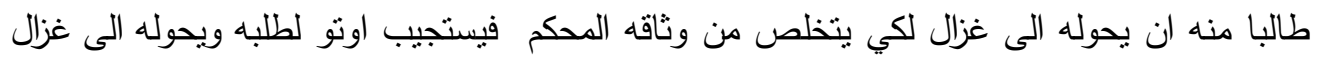
ويهرب بعد ان تخلص من وثاقه الى حظيرة الماشية(^).

ب -ثثيد حظائر الالهة من القصب:

ومن الاستخدامات الاخرى للقصب والتي وردت في الاساطير كان استخدامه في بناء حظائر الماشية

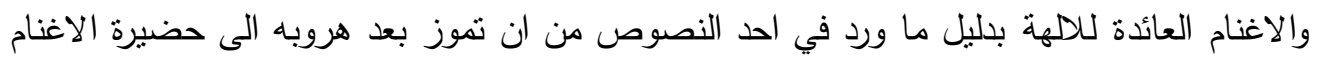

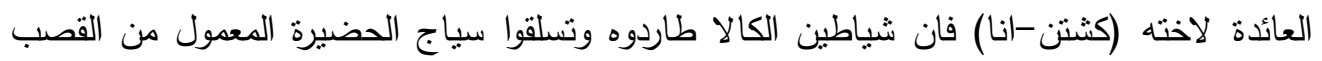

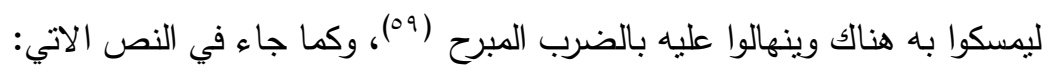

"هرب الى حظيرة اغنام اخته ،..... صعد الكالا سياج القصب، ضرب الكالا الاول

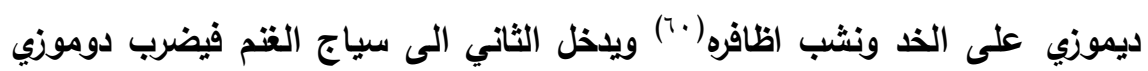

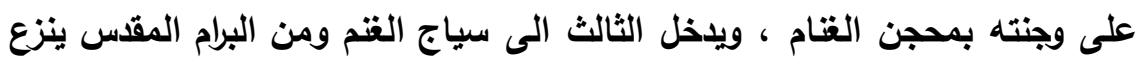

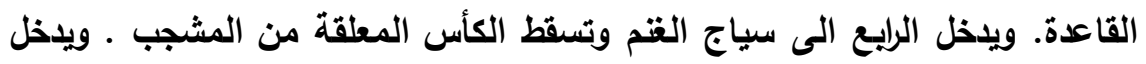

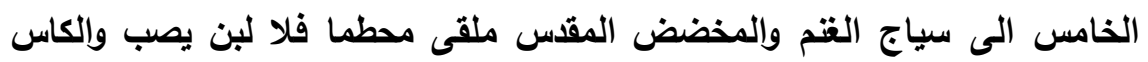

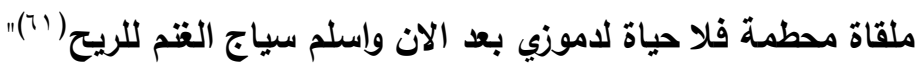

يتضح من النص اعلاه ان الالهة قد سبقت البشر في بناء حظائر الماشية من القصب وهذا الامر

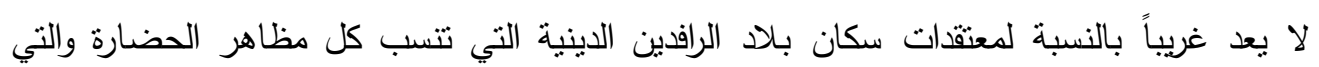

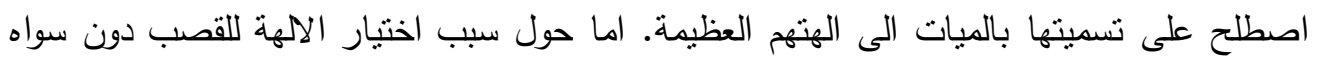
في تثيد هذه الحظائر فيمكن ان نعزوه بالدرجة الاساس الى نوفره بكثرة في بيئة جنوب بلاد الرافدين ذات الاهوار الكثيرة . 
العـــــــــد الثامن والثثلاثون

الجزء الأول / شباط /.r.r.

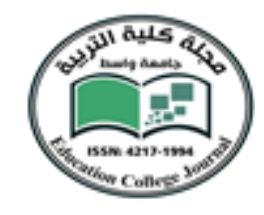

جامعة واسط

مجلـــــة كليـــــة التربيـــــة

ت - استخدام القصب في بناء سفن وزوارق الالهة:

استخدم القصب من قبل الالهة في بناء السفن والقوارب التي كانت كثيرا ما تستخدمها في اثثاء تتقلها

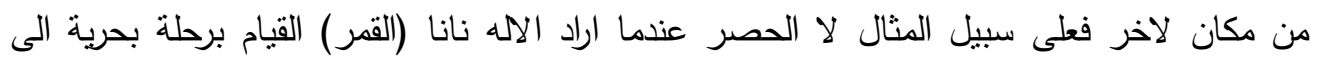

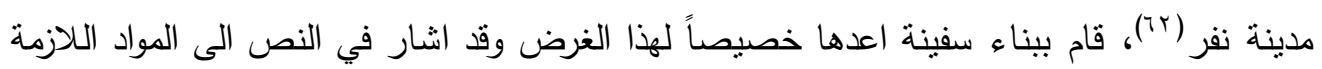

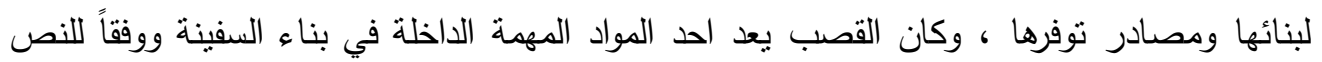

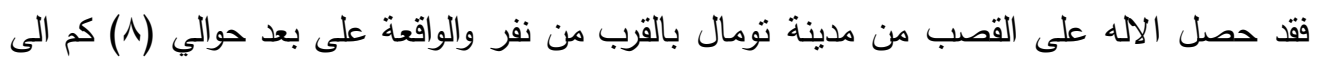

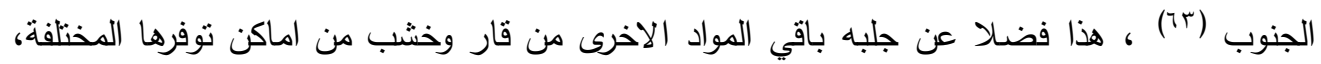

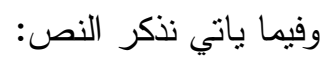

" نانا - سوئين (Nanna-Su'en) (اله القمر) [من اجل ان ييني لنفسه ] ((سفينة

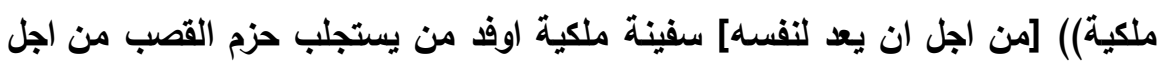
الحصول على قصب السفينة ناناسوئين اوفد مكلفاً الى تومال (Tummal)

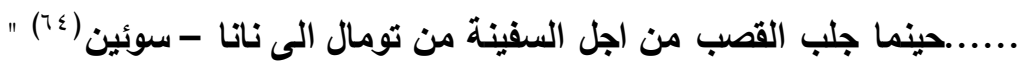

وفي احيان اخرى كان يتم صنع زوارق الالهة بالكامل من القصب فقد وردت اشارة في

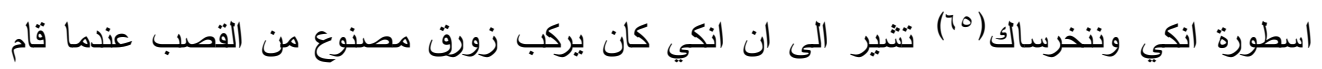

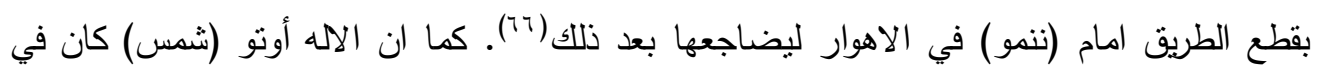

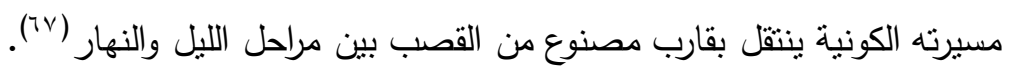

وكانت مجاذيف القوارب تصنع ايضاً من القصب فقد استخدم الاله انكي اعواد القصب

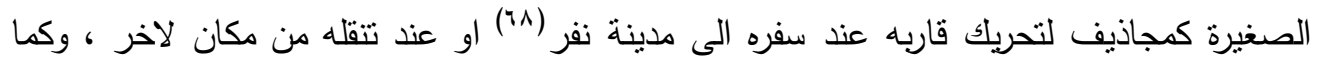

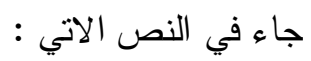

"ان مجاذيفه قضبان القصب الصغيرة . عذما يركب انكي في السفينة ، ..... وتقلع

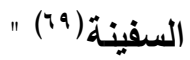


العـــــــــد الثامن والثلاثون

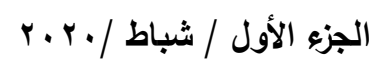

كان من الامور المعتادة عند الالهة تقديم القصب في الهايا التي تهدى فيما بينها ، فعندما اراد الآله

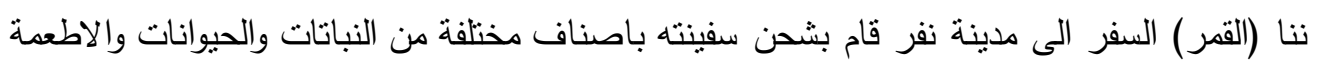
والاشربة. وكان من ضمن ما تضمنته الهابا اعواد القصب الغضة بحسب ما بادئه ورد في النص الاتي:

" ".......... "استحصل اشيمبابار] على فروع قصب (غضة) ونبتات فتية ، من اجل مقر انليل (v•)

ثم انطلق الاله ننا مبندئا رحلته بسفينته من اور مرورا بخمسة مدن منها لارسا والوركاء

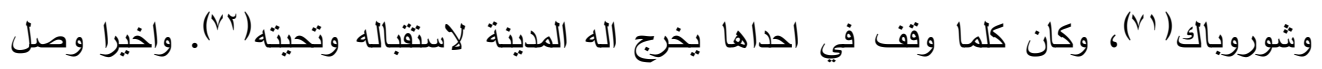
موكب الاله ننا الى نفر حيث يذهب الى حارس معبد انليل اي - كور (é - Kur) ويساله ان يفتح

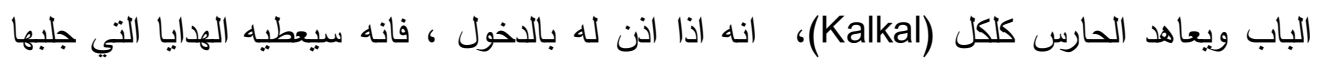

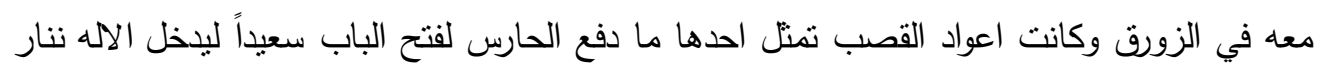

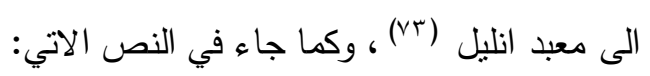

"من اجلي انا ، نانا- سوئين ، افتح المعبد معبد انليل ايها البواب استحصلت على

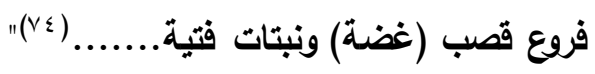

\section{ج-القصب طعاماً في مآدب الآلهة:}

كان القصب يعد من ضمن الاطعمة التي كانت نتناولها الالهة فقد قدم الاله انكي

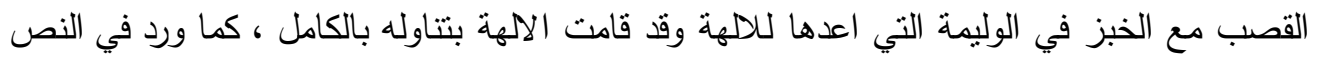
الاتي: - n

"ان الاله انكي جلب البهجة الى قلبهم.....لقد قام باعداد وليمة لامه ناما Namma)

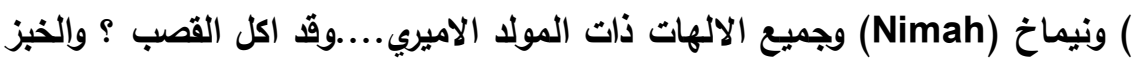

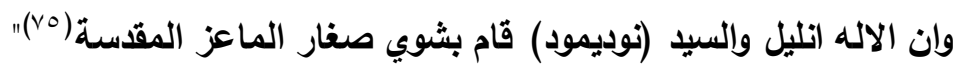


العــــــــــد الثامن والثلاثون

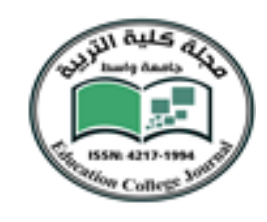

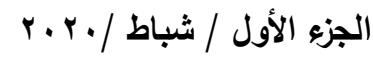

جامعة واسط

مجلـــــة كليـــــة التربيــــة

وتذكر اسطورة انكي وننخرساك ان انكي عندما خرج في احد الايام للتنزه في الاهوار

مع وزيره اسيمود (Isimud) ، كان كلما يجد نبات يسال وزيره عنه فيجيبه عن اسمه ويقطف بامر

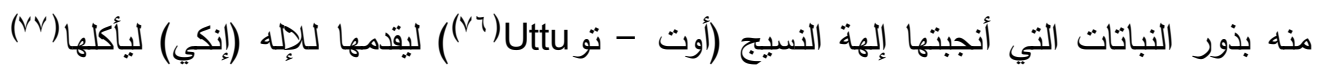

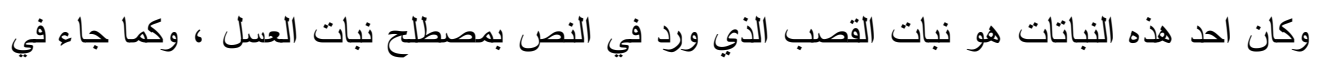

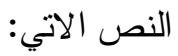

"... إنكي في الاهوار في الاهوار كان يتززه يقول ......إنكي - ما هذا ؟ ما هذا ؟

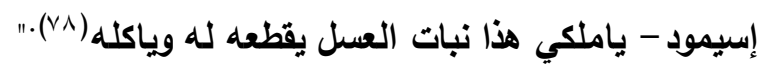

ح-استخدام القصب في بناء بيوت الالهة (المعابد) وييوت البشر:

ومن الاستخدامات الاخرى التي استخدمت فيها الالهة القصب كان استخدامه في بناء

بيوتها ففي نص (انكي وبناء البيت)(19) قام انكي اله الابسو ببناء معبده في اريدو فوق الغرر مستعينا بالقصب الذي بنى جدران منزله منه مزينا اياه بالمعادن الثنية والحجار الكريمة، وكما يذكر

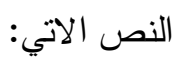

"قام انكي ببناء قصر من الفضة والللازورد . فضته ولانورده يسطعان كضوء النهار نشر هذا المقام البهجة في الابسو وكاتت جبهاته في بروزها الساطع تتصب امام الاله نوديمود (انكي) اقامه حينئ من الفضة المزينة باللازورد والمطعمة ذهباً بسخاء اقامه في اريدو على الشاطيء اقام هذا القصر • كان اجره ، يرجع صدى الاف الاصوات وجدرانه القصبية تسمع خولارا ، كمثل الثيران .....يا قصر اتجور (Engur) (ابسو) حيث قام انكي (شخصيا) بجل قصب التصوينه المقدسة فيك انت نصبث المنصة العالية(·)" التصنية

ومن الامور المهمة التي يمكن ان نستتجها من النص المذكور انفاً ان بناء بيوت الالهة كان يقع على عاتق الالهة نفسها منذ اقدم الازمان . ولكن بعد ان قامت الالهة بخلق الانسان اصبح بناء نلك البيوت مناط بالانسان نفسه ، ويبدو ان القصب لم يفقد اهميته في بناء بيوت الالهة حتى بالنسبة للانسان عند قيامه بهذا العمل فقد ذكرت اسطورة (حينما خلق انو السماوات)( (ال) فيام الاله انكي بخلق القصب من اجل اتمام عمليات بناء المعابد وهي البيوت التي تأوي اليها الاههة، ويبدو ان ذكر خلق القصب هنا جاء تأكيداً لاهميته في اعمال البناء اذ انه لا يقل اهميةً عن باقي 
العـــــــــد الثامن والثلاثون

المواد الاخرى المستخدمة في عطلية بناء المعابد كالطين والخشب ، وكما نستشف ذلك من النص الاتي:

"عندما قام "انو" بخلق السموات، (و) قام "توديمود" بتثييد الل"ابسو" تماماً له، قطع

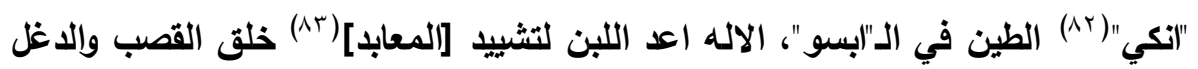

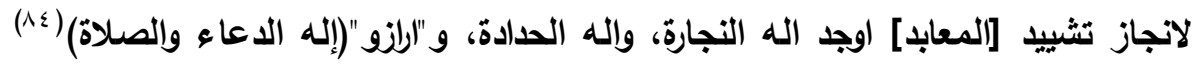

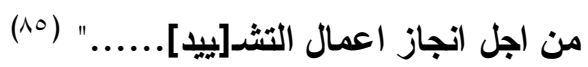

ولم يقتصر استخدام القصب على بناء بيوت الالهة وحسب فقط وظفته الالهة في بناء بيوت البشر

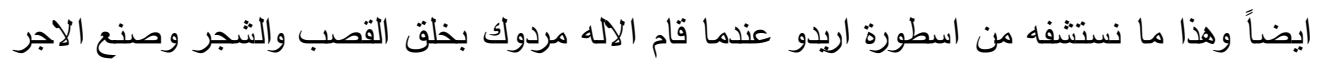

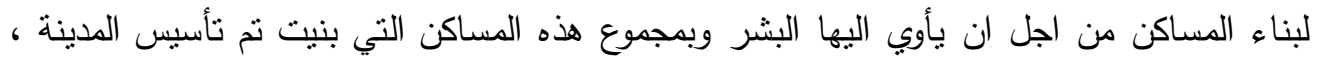
وفيما ياتي نذكر النص:

"خلق القصبة وخلق الشجرة ـ خلق.....في الموضع قطع لبناً وصنع قالب الطابوق ، بنى

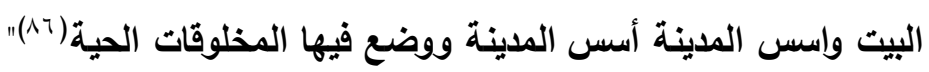

نستتنج من النص اعلاه ان سكان بلاد الرافدين قد استخموا القصب مع الطين والخشب في بناء اول

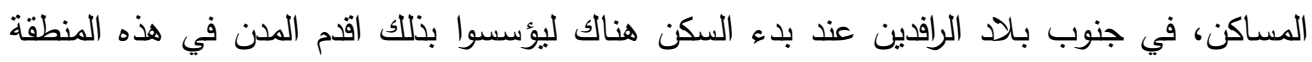

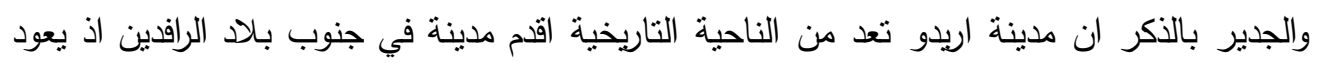
استيطانها الى اقدم اطوار دور العبيد وهذا الدور يمثل اول استيطان للانسان في المنطقة وفقاً للاليل بليل

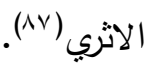

\section{خ-استخدام القصب في صنع اثاث الالهة:}

لم تقتصر فائدة القصب على استخدامه في بناء بيوت الالهة والبشر فقط استخدم

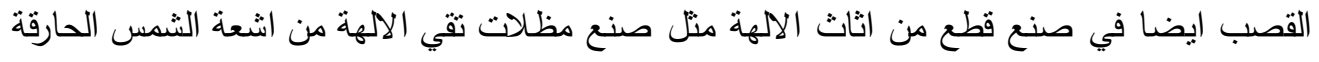

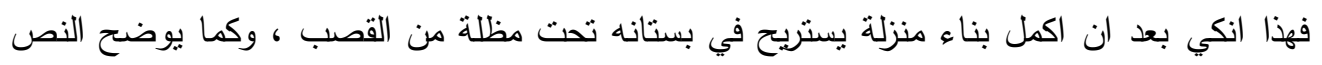
الاتي:

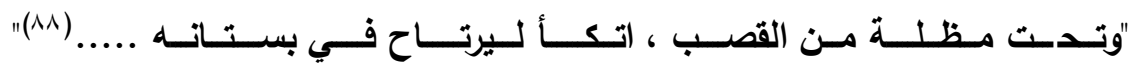


العـــــــــد الثامن والثلاثون

ومن قطع الاثاث الاخرى التي صنعت من القصب كان صنع اريكة من القصب تسنلقي عليها الامهة، ففي احد النصوص يظهر الآه انكي وهو مستلقي على اربكة من القصب في حديقته الخضراء. ولا يستبعد ان هناك قطع اثاث كانت تصنع من القصب في المعابد(ه)، وفيما ياتي نذكر النص : n

"لما رفع انكي اريدو ، صارت حصناً منيعاً كجبل مدرج شيد على الماء ، وعلى طرف

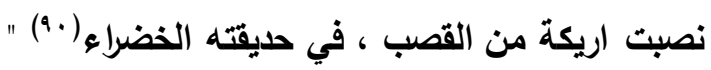

د -استخدام القصب في اقامة السدود لتجفيف اراضي الاهوار واصطصلاحها : تعزو اسطورة اريدو الى الالهة تعليم البشر كيفية السكن في الاهوار من خلص اقامة السدود لتجفيفها

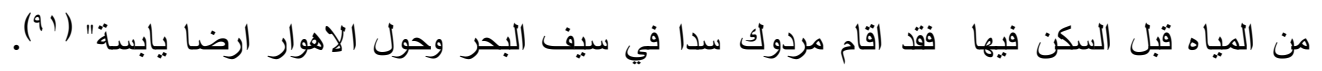
وكما جاء في النص الاتي:

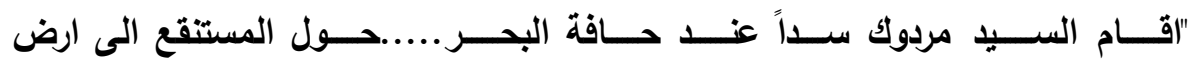

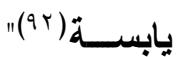

وقد ورد في اسطورة اريدو ما يشير إلى قيام الآلهة ببناء هذه السدود في الاهوار من اجل احياء الاراضي التي بديء السكن فيها هناك وذلك باستخدام القصب والتراب لانشاء ضفاف حول مساحات معينة من الاراضي المغطاة بالمياه وفي داخل هذه الاراضي المسيجة بعد جفافها اقيمت معابد الالهة

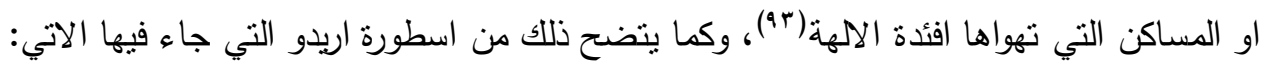
" وحيث يقيم الاله العظيم الممجد غرس مردوك القصب ليقف حائلا بوجه الماء واقام الضفاف الترابية ودعمها بالقصب ليهى لكلالهة مسكنا في المحل الذي تثوق اليه

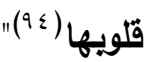
نستتج من النص الانف الذكر ان بلاد سومر كانت فيما مضى عبارة عن اهوار لم يكن فيها سوى مواطن قليلة مبعثرة من مستوطنات الانسان الامر الذي تطلب من الساكنين في هذه المنطقة العمل بجد وعزيمة لا تفتر وعبر اجيال كثيرة لتصبح هذه الاهوار مدن وقرى عامرة يشار اليها بالبنان. 
العـــــــــد الثامن والثثلاثون

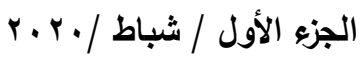

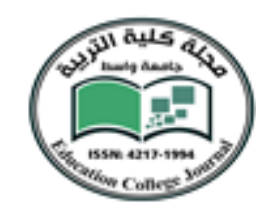

جامعة واسط

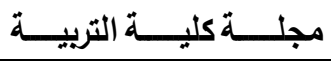

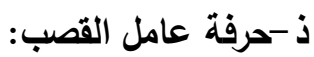

تعد حرفة عامل القصب من الحرف التي ورد ذكرها في الاساطير والتي كانت تعتمد بالدرجة الاساس على القصب في صناعتها فقد وردت " حرفة عامل القصب " من بين عناصر الحضارة (الميات(ME

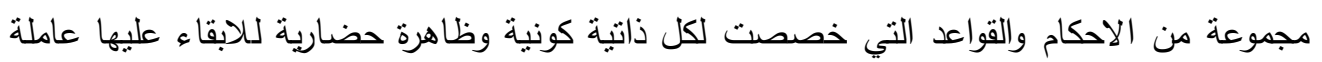

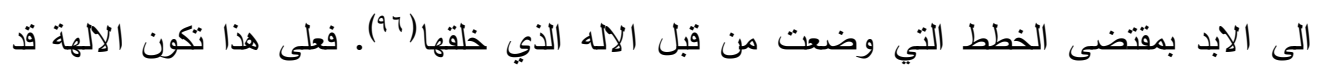

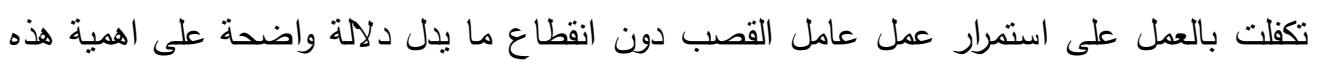
الحرفة عند سكان بلاد الرافدين.

كما ان الالهة تكفلت بعطلية تامين بكل ما تحتاجه هذه الحرفة من مواد اولية سواء ما يتعلق بالقصب

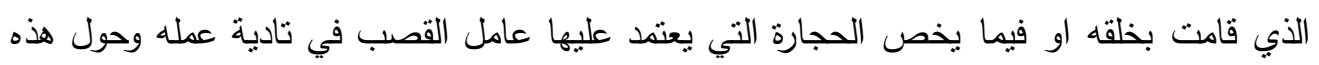

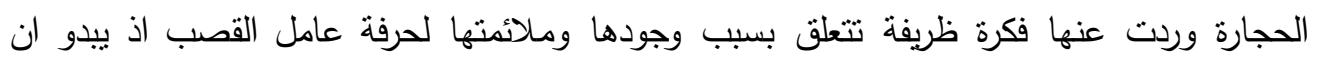

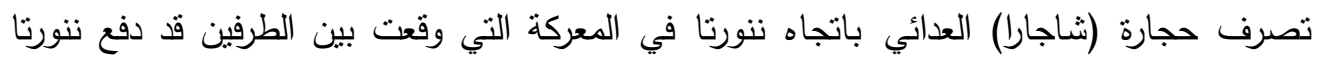

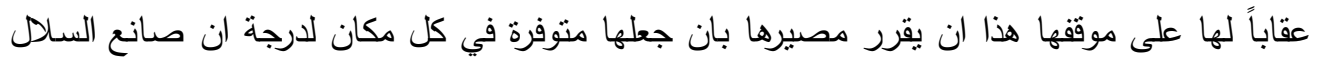

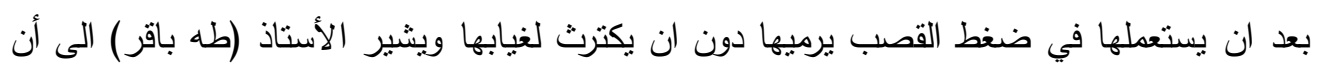

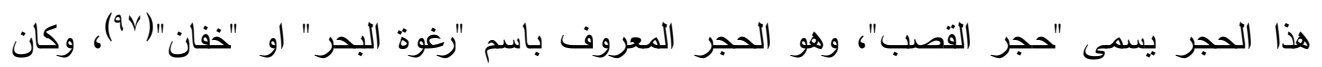

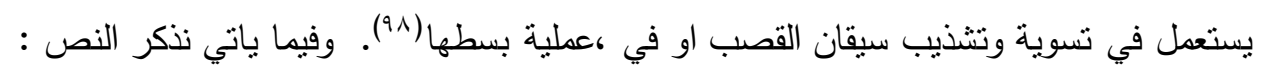
"ثاجارا (shagara) في الجبل حاولت دوسي بقميك بينما كنت منشغلا في الحرب ولاتك وجلت

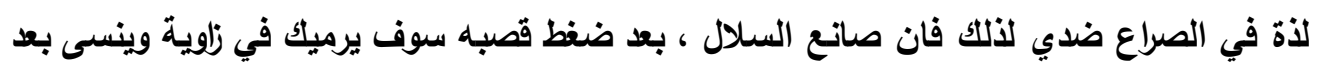

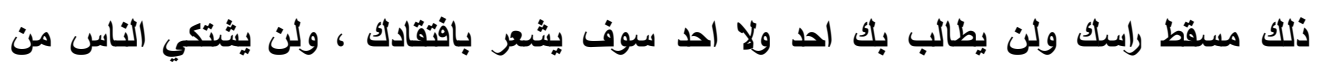

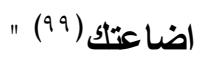

رايعاً - الاخطار التي تهدد حقول القصب بالامار في الاساطير :

على الرغم من الفوائد الكثيرة التي يمنلها القصب بالنسبة للالهة والبشر على حد سواء فقد كانت كثيراً

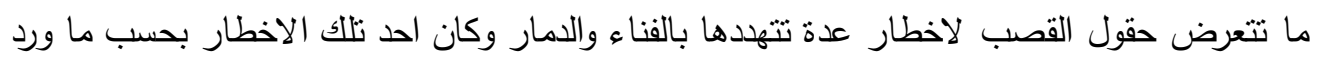
في الاساطير المعارك التي تحدث بين الالهة ففي المواجهة التي وقعت بين الآله ننورتا واساكو (...) 
العـــــــــد الثامن والثلاثون

على اثر استمرار التمرد في المنطقة الجبلية قام اساكو بصب جام غضبه على حقول القصب التي

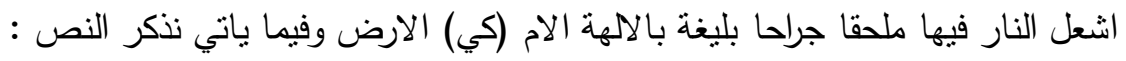
"ثم مزق جسد الارض وغطاه بجروح وحثية اشعل النار في المقاصب ، واذا بالسماء

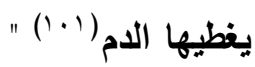

وهنا لم يدخر ننورتا جهاً في مواجهة اساكو فقد جرت بين الطرفين عدة منازلات وفي المنازلة الاخيرة

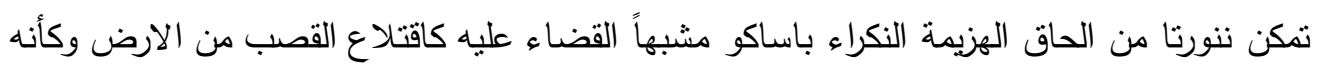

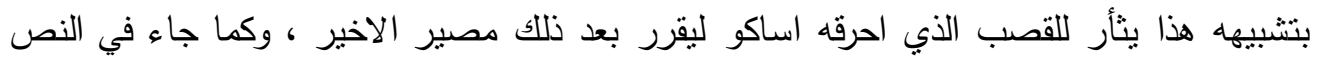
الاتي:

وعندما وهن بريق الاساكو الخارق للطبيعة [....] رمى به ارضاً ، ثم قذفه نحو

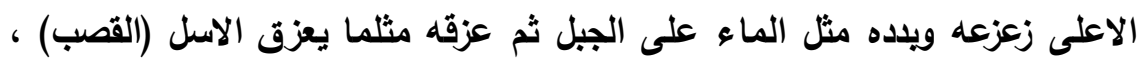

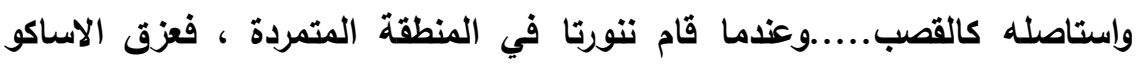

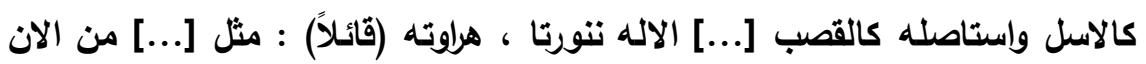
فصاعداً ، لن تسمى اساكو بل تسمى حجراً ( + ()"

وكانت العفاريت تشكل خطر ايضاً على القصب فعفريتية الاحلام ابنة الاله انو التي هي العين

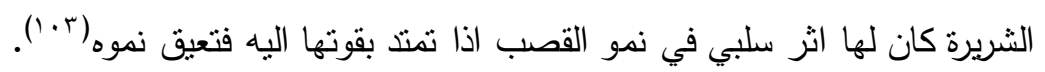

ومن الاخطار الاخرى التي كانت تهدد حقول القصب بالدمار الشامل كان تعرضها لخطر الحرائق

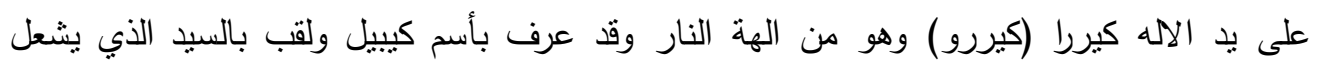
القصب(ء +1). وكما جاء في النص كيرل (كيرو) وهو من الاتي:

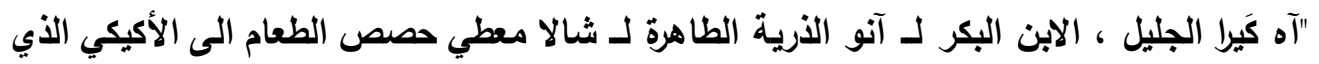

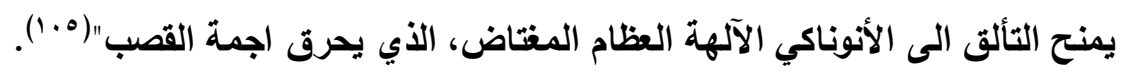
كما ان الفيضان كان يعد خطراً اخر لا يقل شراً عن النار في اللحاق الاذى بحقول القصب فكما هو

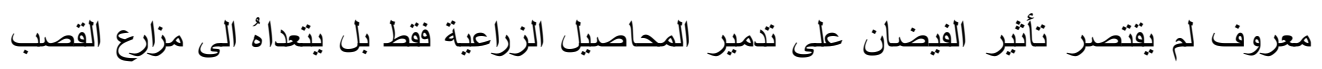


العــــــــد الثامن والثلاثون

والغابات إذ قد بطالها الفيضان بتدميره الثامل إذا كانت مياهُُ كثثرة وجارفة على بد الاله أدد، إذ

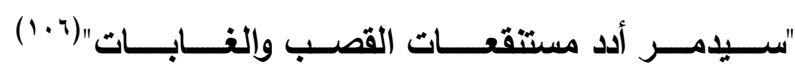

خامساً - دور الالهة في تحقيق البركة والخصب في حقول القصب:

كان زيادة انتاج حقول القصب من اولى المهام التي تضعها الالهة بين نصب اعينها ومن اجل تحقيق هذا الهُف السامي لم تكن تتوانى تلك الالهة عن القيام برحلات بعيدة المسافة عن مدنها

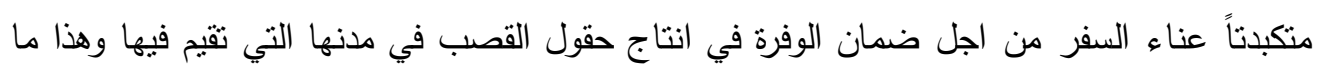

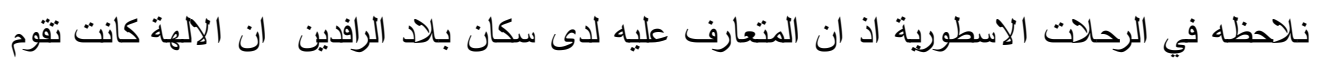

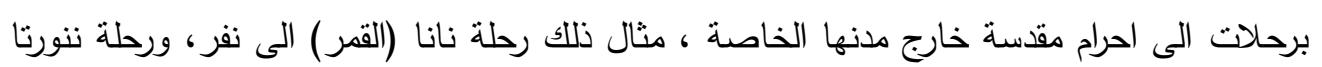

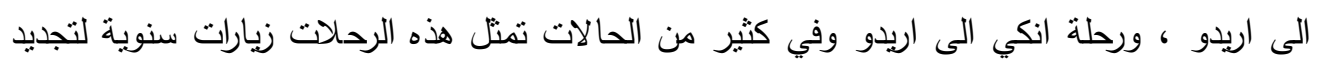

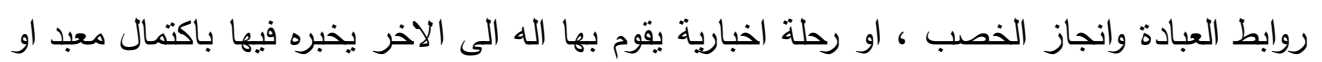

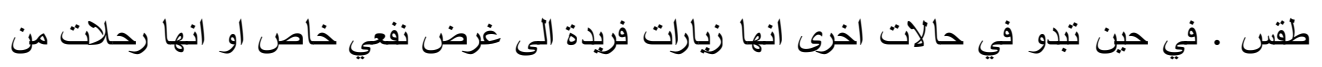

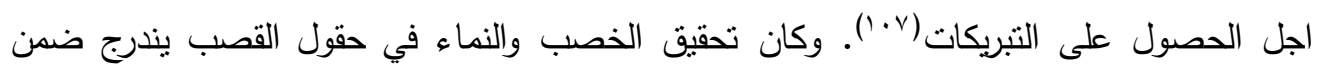
النوع الاخير من الرحلات كما هو الحال في رحلة نانا الى نفر فقط سال اله القمر (نانا/ سين) اباه

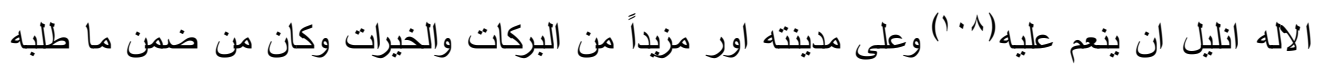

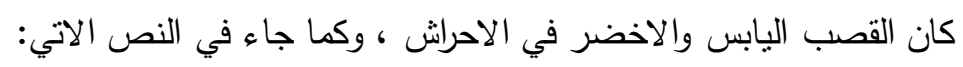
"فـي النهــر اعطنــي مـزيـــاً مــن الاسمـــاك اني ذاهــب الى اور، في الاحراش اعطني القصب اليابس والقصب الاخضر اني ذاهب الى اور(9 (1)" ومن بين الاشياء الاخرى التي طلبها الاله ننا: فيضان مبكر في الفرات لكي بستطيع العودة الى اور

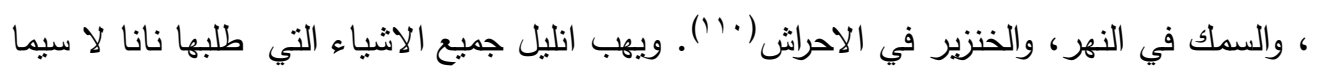
القصب ، كما جاء في النص الاتي: والنزبر في الاحت

" منحه (اي انليل) القصب الغض والنبتات الفتية في المقاصب قبل عودته الى اور (1) (1) (1) 
العــــــــــد الثامن والثلاثون

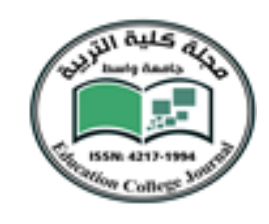

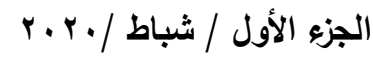

جامعة واسط

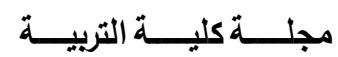

عندئذ يعود الاله نانا الى اور(r(I) ، ان طلب نانا من انليل وفرة في اجمات القصب الذي يعد البيئة المثالية لمختلف الحيوانات والطيور يؤكد على اهميته بالنسبة لاقتصاد مدينة اور في تحقيق الرفاه من لمن خلال فرص العمل المتحققة من صيد السمك والحيوانات والطيور المختلفة التي تعيش في اجمات القصب هذا فضلا عن المهن المعتمدة اصلا على القصب في صناعتها.

ومن الرحلات الالهية المقدة الاخرى التي كان الغرض منها احلا البركة والخصب في حقول القصب كانت رحلة ننورتا الى الاله انكي في مدينة اريدو اذ يفصح ننورتا عن سبب ذهابه في النص الاتي قائلا:

" لكي [ يتكاثر] في الاحواض شبوط المستثقعـات ، والشـبوط الضخم ، ويين

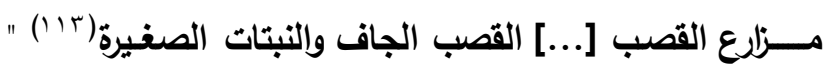

وبحسب معتقدات سكان بـلاد الـرافـديـن كان يعـ الاله انكي مـن الالهة المســؤولة عن احلال

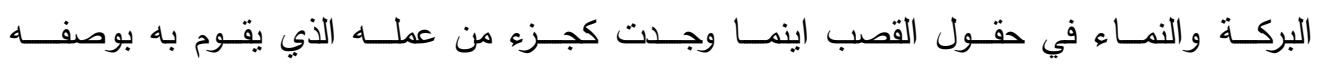

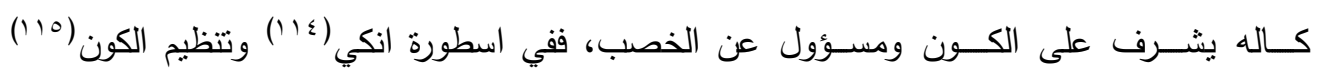
يصف لنا هذا الاله رحلته المتعة في الاهوار في قاربه الـ (ماجور Magur) المصنوع من القصب الذي سماه (وعل الأبزو) تلك الرحلة التي ارسلت بعدها بلدان مكان (عمان) ودلمون (البحرين) وملوخا (الراجح انها الهند) سفنها المنقلة بشحنة من الهدايا الثمينة للإله (أنليل) في نفر · وبعد فقرة اخرى لا يمكن التأكد من محتوياتها لأنها مهشمة، نجد إنكي في قاربه مرة اخرى. وبقيام مخلوقات البحر بتقديم الولاء له، وانتشار الخير العميم في الكون اصبح (إنكي) مستعدا "لتقدير المصائر" مبتدئا، ببلاد سومر نفسها، فرفع من قدرها كبلاد مختارة مقدة(1/17)، بـ ((ميات)) (اي النواميس)

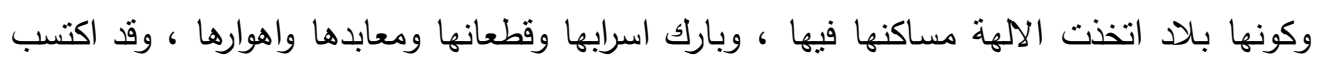
القصب الذي ينمو في الاهوار أهمية كبيرة عند سكان بلاد الرافدين، ودليلاً على أهميته في حياتهم

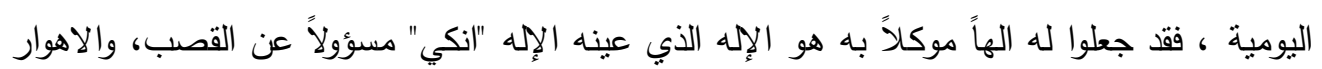
كما ورد ذلك في "أسطورة انكي وتنظيم الكون "('lv').

اذ تخبرنا عنه الاسطورة السومرية، انه " كان يحب السمك "(1'1)، الا ان اسمه غير واضح لتهشمه، بحسب ما ورد في النص الاتي: 
العـــــــــد الثامن والثلاثون

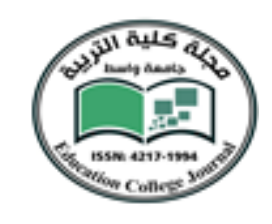

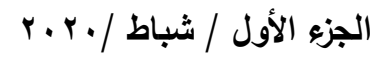

جامعة واسط

مجلـــــة كليـــــة التربيـــــة

"انكي....تحكث الى المستنقع واعطاه سمك الشوارب ، تحدث الى القصب واعطاه الرؤوس الحمراء والسويقات الخضراء.....من شبكته ، لا تتجو سمكة ، من شركه ، لا لاه ينجو حيوان ، ومن عينه ، لا يغرب اي طير ، ....نانار ، الذي يحب السمك ، وضعه

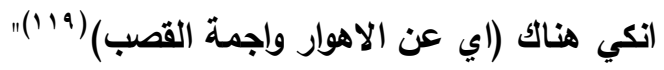

ثم يذهب انكي نحو الشرق الى ارض ملوخا(·r). ومما يدعو الى الغرابة ان نجد موقف انكي ازاء ملوخا ودياً للغاية كما هو موققه ازاء سومر بالذات . وكان من بين ما باركه انكي في هذا البلد فضـال

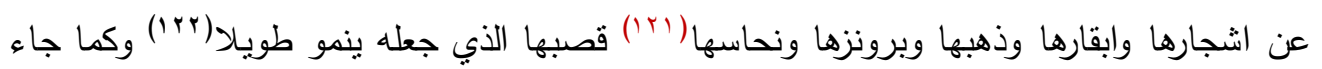

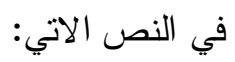

\section{"وعسى ان يكون قصبك كبيراً، [عسى ان يكون] قصب [الجبل] (rr)")}

اما في اسطورة انكي وننخرساك فيقوم انكي بارواء حقول القصب بمائه اذ يقوم باخراج

قضيبه ليروي بمائه الأخاديد في الأرض فجرى الماء في الانهار الصغيرة والكبيرة ، وغمر حقول القصب(ءזl) . . وفيما يخص ارواء حقول القصب بماء انكي يشير الباحثان (ديكسون) (Dickson) وليكي (Leick) الى ان القصب الذي هبط فيه قضيب انكي ربما يشير الى مفهوم (مثيوبويكالي) كناية عن شعر العانة في الارض الام(') (mythopoeically) "وحده انكي الفطن وامام نينتو (نتخرساك) ام البلاد انكي الحاذق ، امام نينتو ام البلاد ملأ بماء قضيبه المجاري جمعاء ، ويماء منيه الغزير ، اغرق منابت القصب، ممزقاً

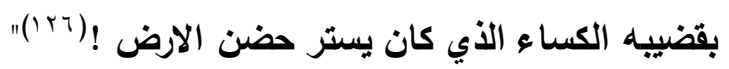

وبحسب ما ورد في اسطورة انكي وتتظيم الكون فان الاله انكي قد اقام بيته في اعماق المستقعات فيما كان معبده شعار لله على سطح الارض وكما جاء في النص الاتي:

"ظل الشعار الكبير ، لحماية ابزو اقيم عليه ، ينتشر فوق سطح الارض ، والتاس ترنو اليه ، والمعبد في اعماق المستقعات شيد وعلى الارض الغزيبة يسمو السيد ، حاكم

(بزو الكبير (بrv) 
العــــــــــد الثامن والثلاثون

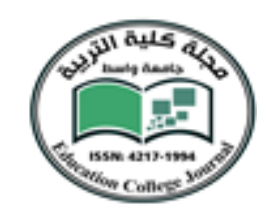

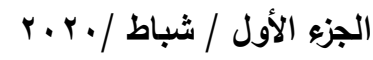

جامعة واسط

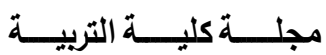

وكما هو معروف ان بروز اسم انكي وتطوره الى ايا حدث في مدينة اريدو، في اقصى الجنوب، حيث تسود المستتقعات ، وندرك معنى تطور التسمية الثانية التي لازمته اي (مقر المياه) ـ كما تلازم هذا الاله ، في النصوص، صفة (سيد ابسو) اي سيد المياه المحبوسة، وقد عرف معبده في اريدو باسم

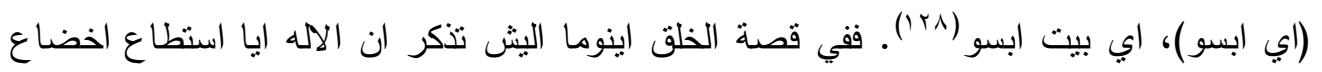
(ابسو) اي المياه برقية سحرية، فجعله مشلولاً، وسجنه واقام مقره فوقه، بسلام ومن هنا جاء لقب هذا الاله ملك ابسو، وبيدو ان هذه الاشارة الى سجن ابسو لم تكن سوى وصف لحالة المياه العذبة، المجتمعة في مستنقعات جنوب العراق ، حيث يسنطيع الانسان الحياة فوق الجزر الصغيرة الكثيرة، التي تتنشر في هذه المستتقعات، دون خوف من طغيان المياه ـ كما يحدث عند انحراف مجرى نهر

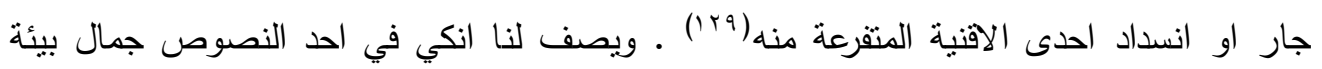
الاهوار موطنه(·rا) حيث احراش القصب والاسماك والطيور التي تعيش هنالك قائلاً:

"دار تلقي بظلالها على المستنقعات ، مسكني ، حيث الاسماك طويلة الشارب ، تقترب من النباتات والثبوط هناك يتشلل بين القصب بزعانفه ويشير الماء موجات ، والطيور من اعشاشها تزقزق

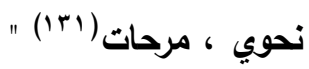

واذا كان انكي يرى في الاهوار مكاناً جميلاً ذو طبيعة غلابة فان البعض الاخر من الاههة كانت ترى فيها خلاف ذلك اذ ان انتشار اجمات القصب الكثيفة في الاهوار قد جعل منها مكاناً مثالياً لتنفيذ جرائمها النكراء فهذا انليل يقوم من اجل اغتصاب ننليل بالاتفاق مع وزيره نوسكا بوضعها في زورقه الملكي الذي تغلغل به بين احراش القصب ليغتصبها هناك متخذا من القصب سدا منيعا يقيه من اعين المنطفلين وارجل الغرباء ، وكما ورد في النص الاتي:

" لم يلجها احد بعد ، لم يجامعها احد عند ذلك زود الخادم (اي نوسكا) سيده بتفصيلة قارب وسلمه ما يشبه قلس الربط وجلب له ما يشبه القلك الكبير تغلغل الملك بين القصب ضاجع نتليل وجامعها

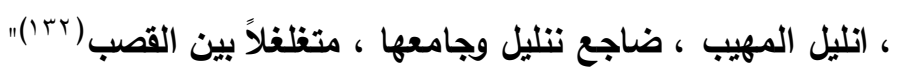
ولا يستبعد ان جرائم من هذا النوع كانت تحدث فعلا بين اجمات القصب من بعض ضعاف النفوس في ذلك الوقت. 
العــــــــد الثامن والثلاثون

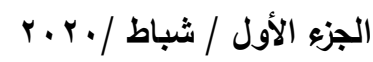

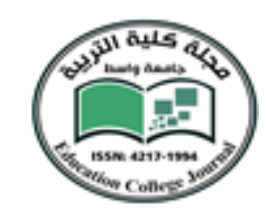

جامعة واسط

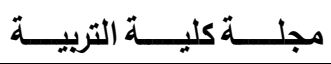

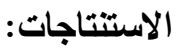

1 - من خلال ما استعرضناهمن اساطير في البحث فان عملية خلق القصب كانت تحصر بيد ثلاثة

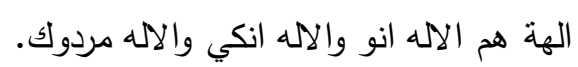

r - كان للقصب دور في خلق الكون من خلال قيام الاله مردوك بحياكة بناء من القصب فوق

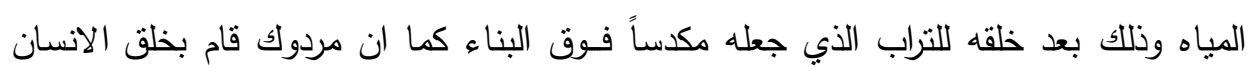

$$
\text { من خلال وضع طيناً في قصبة. }
$$

r- في ضوء ما ورد في اساطير بلاد الرافدين كان للقصب استخدامات عدة منها استخدامه في

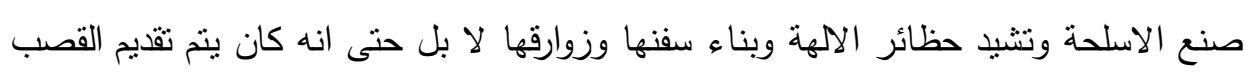
كهايا وطعام ينم تتاوله من قبل الاههة، هذا فضلاً عن استخدامه في بناء بيوت الالهة (المعابد)

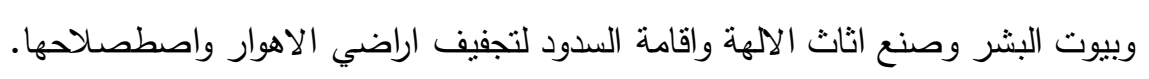

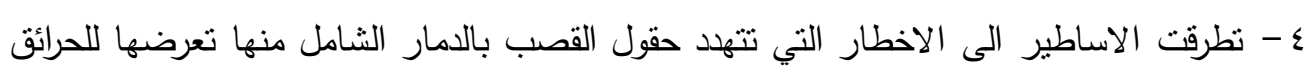

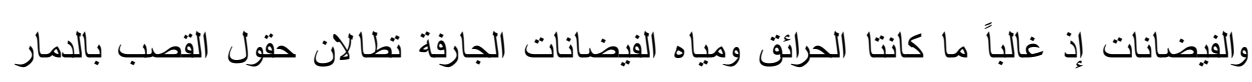
الشامل. ه - يتضح من ما ورد في الاساطير ان للالهة كان لها دور كبير في تحقيق البركة والخصب والنماء في حقول القصب من خلال الرحلات الالهية المقدة التي ثقوم بها الى الاحرام المقدة خارج مدنها الخاصة.

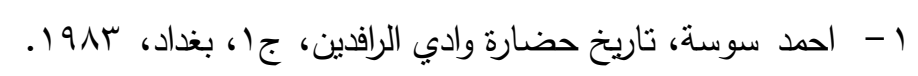

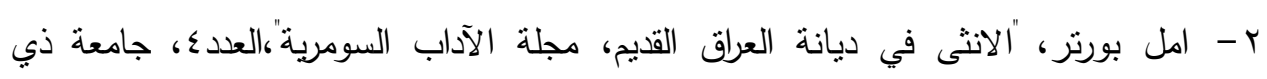

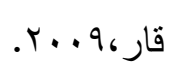

r- انطوان مورتكات، الفن في العراق القديم، ترجمة عيسى سلمان وسليم طه التكريتي، بغداد، $.19 \vee 0$ ع - انيس فريحة، ملاحم وأساطير من الادب السامي، طץ، بيروت، 19 1979. 
العـــــــــد الثامن والثلاثون

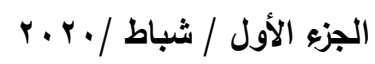

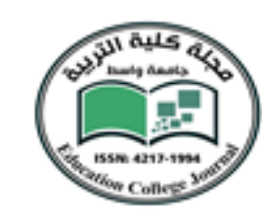

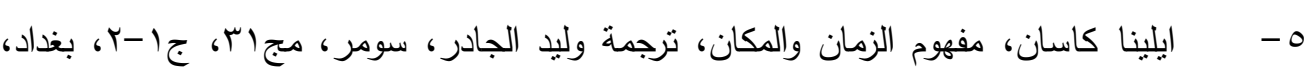
$.19 \vee 0$

7 - بوهوسلاف هروشكا واخرون، الاساطير في حضارة وادي الرافدين، ترجمة عصام عبد

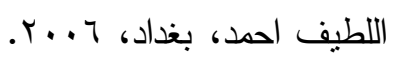

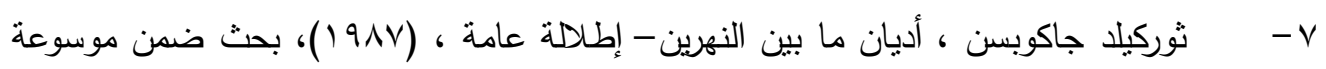

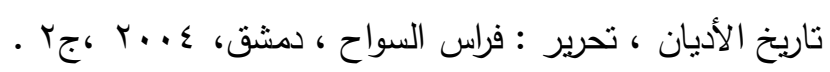

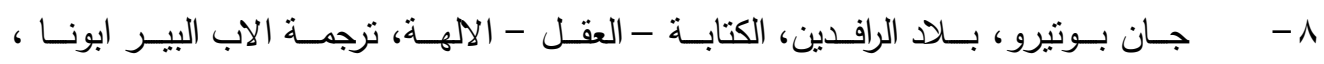
مراجعة وليد الجادر، بغداد، . 199.

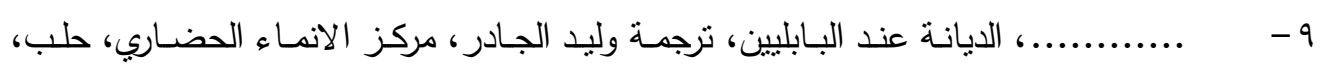
.+.0 • - جفري بارندر، المعتقدات الدينية لدى الشعوب، ترجمة امام عبدالفتاح امام، مراجعة

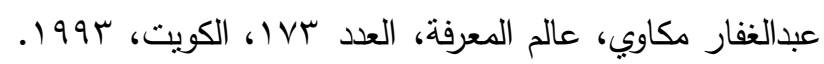

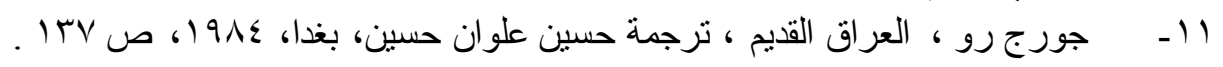

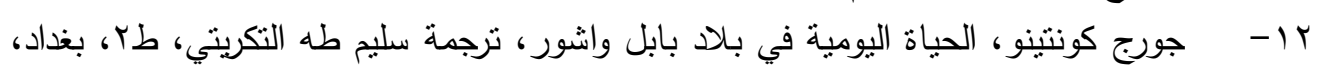
.1917

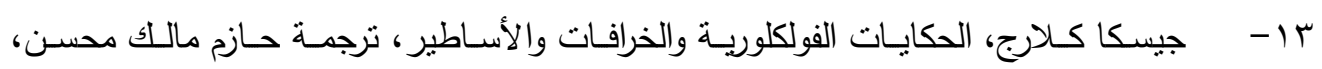

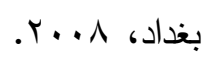

§ ا - بيمس برتشارد ، أساطير بابلية، ترجمة سلمان التكريتي، مراجعة زكي الجابر، النجف، $.19 \vee r$ 10- حسن فاضل جواد، حكمة الكلانيين ، القسم الاول مقدمات ونصوص، مراجعة عبد الامير

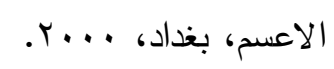

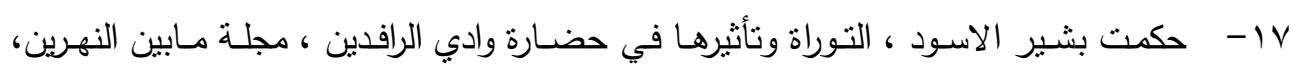

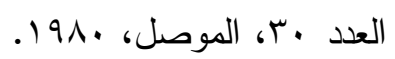

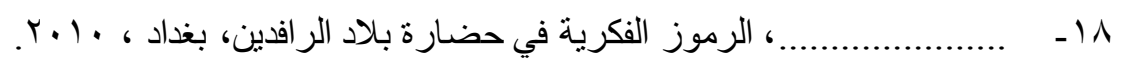

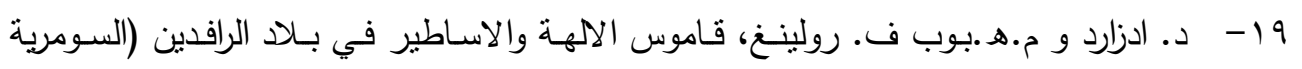

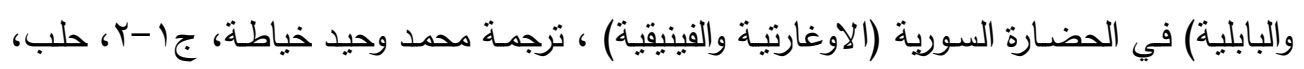


العــــــــد الثامن والثلاثون

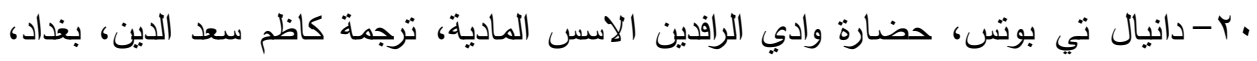
. . . .

اب - دايان ولكثتاين وصموئيل نوح كريمر، اينانا ملكة الارض والفردوس اسطورة بلاد ما بين

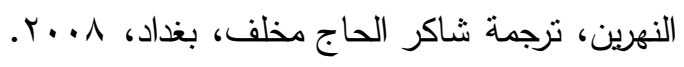

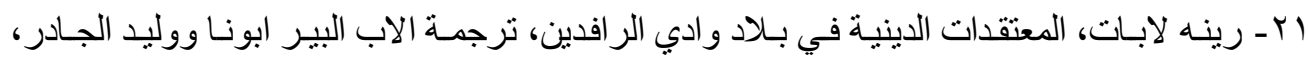

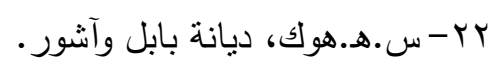

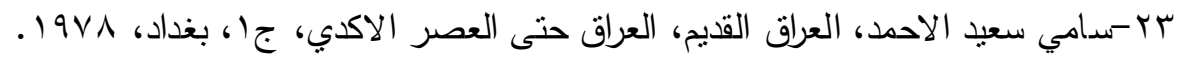
rr -................... العراق القديم من العصر الاكدي حتى نهاية سلالة بابل الأولى ، المدخل

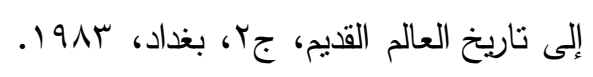

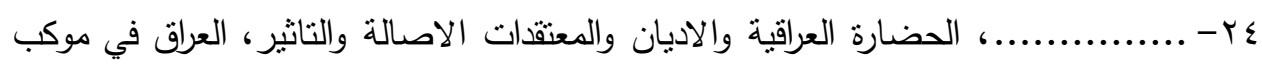

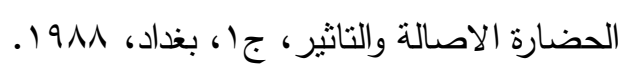

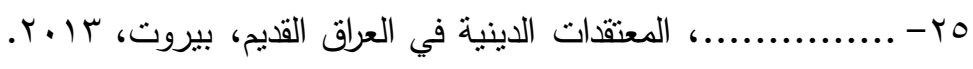

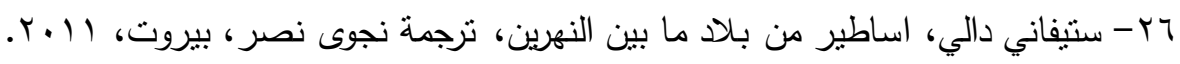

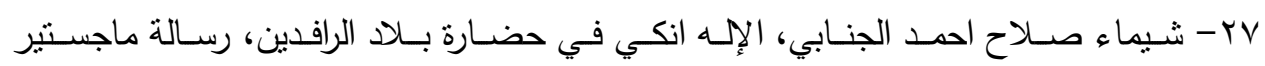

$$
\text { غير منشورة، جامعة بغداد، كلية الآداب، V. V. V. }
$$

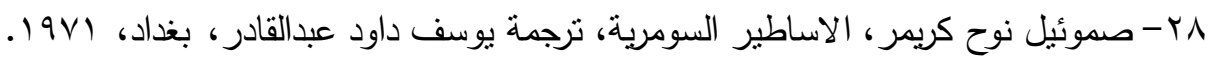

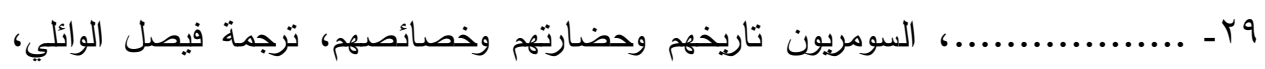

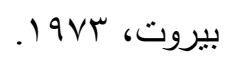

• . ........................... اساطير سومر واكاد، اساطير العالم القديم، ترجمة احمد عبد الحميد.

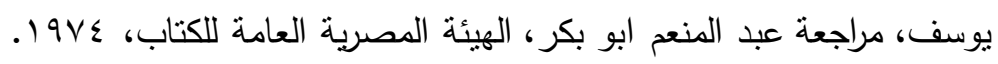

اب-........................... من الواح سومر ، نرجمة طه باقر، مراجعة احمد فخري، بغداد،

.$r \cdot 1$.

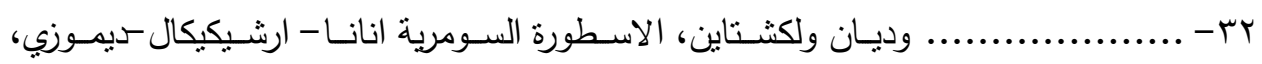

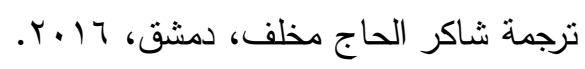

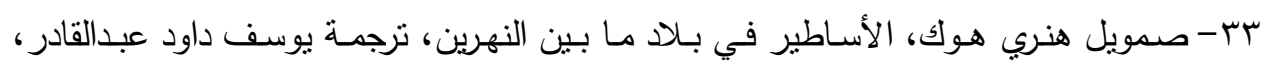


العــــــــد الثامن والثلاثون

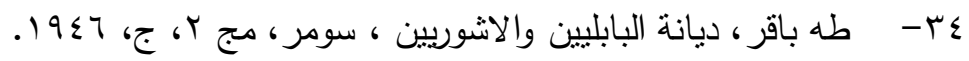

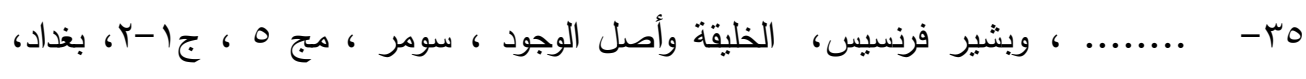

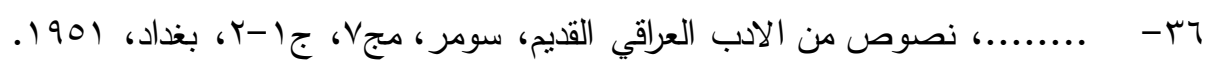
V $.190 r$

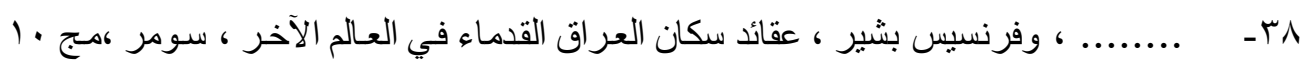

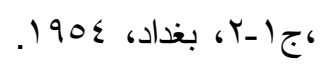

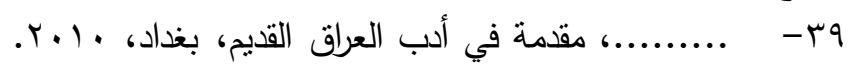

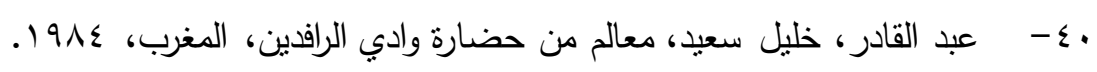

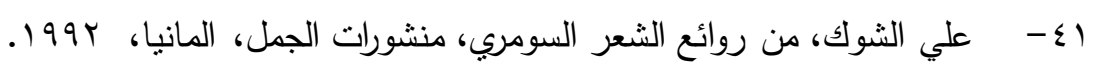

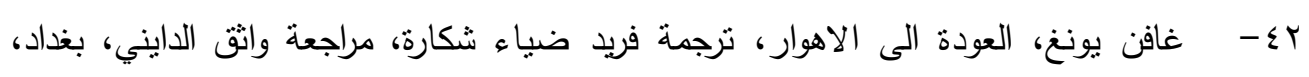
.199.

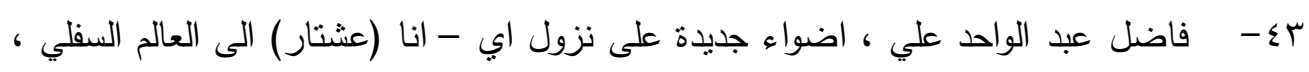

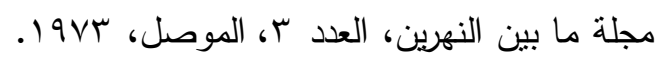

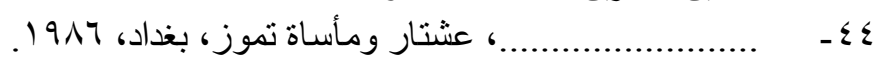

؟

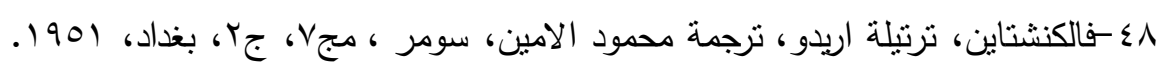

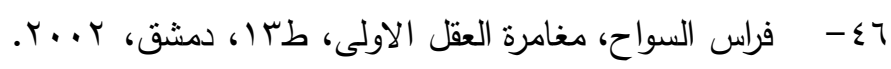

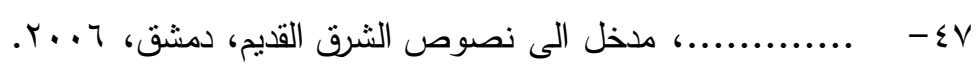

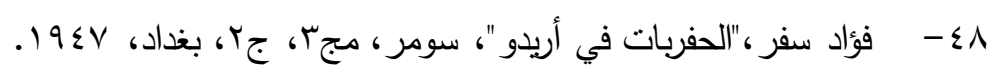

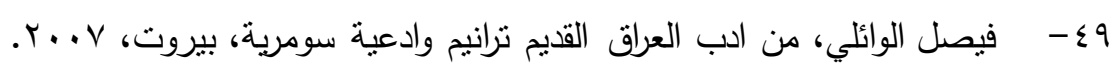

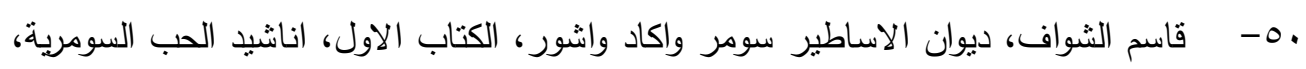
بيروت، 1997.

10. ................... ديوان الاساطير سومر واكاد واشور، الكتاب الثالث الحضارة والسلطة، 


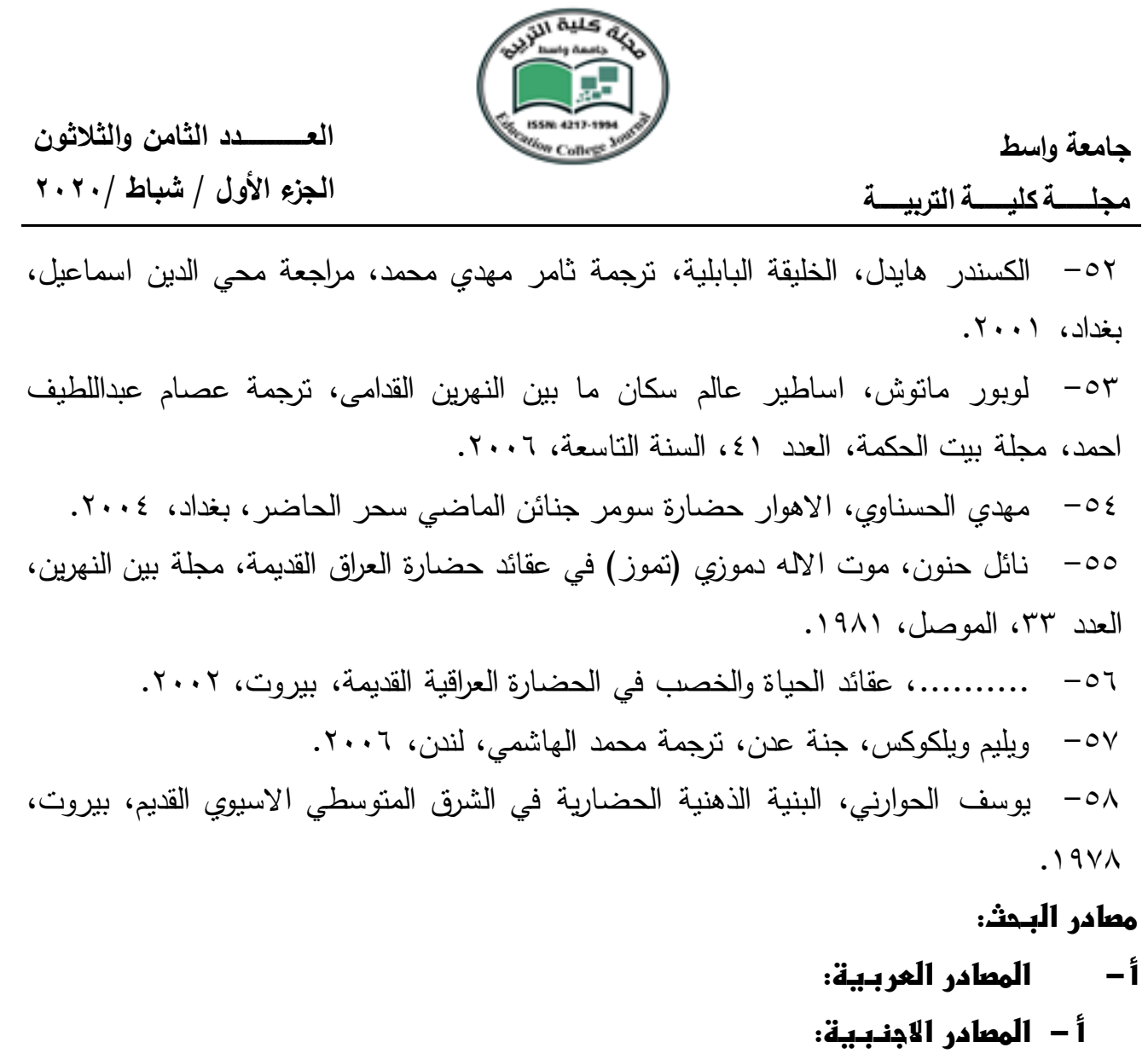

1- $\quad$ Al - Fouadi, A. Enki Journey to Nippur the Journey of the Gods, London, 1969.

2- Bottero, J., Every Day life in Ancient Mesopotamia, translated by Antonia Nevil, Creat Britain, 2001.

3- Dalley, S., Myths from Mesopotamia Creation, the Flood, Gilgamesh and Others , Oxford , 1989.

4- Dickson, Keith, Enki and Ninhursag; The Trickster in Paradise, JNES, VOL.66, NO.1, 2007.

5- Ebeling, J and Cunningham, G, The Electronic Text Corpus of Sumerian Literature, London, 2007.

6- Ferrara, A. J. Nanna Suen`s Journey to Nippur, Rome, 1973.

7- Fish. T., "The Zu Bird" in the Bulletin of the John Byloands Library. XXXI., 1948.

8- Frankfort, H., and others, The Intellectual Adventure of Ancient Man, Chicago, 1946.

9- $\quad$ Frankfort, H., King Ship and the Gods, Chicago, 1955.

10- Grayson, A., The Myth of Zu", ANET, 1969.

11- Heidel, A. The Babylon Genesis (BG), Chicago, 1967.

12- Heimpel, Wolfgang, The Natural History of The Tigris According to The Sumerian Literary Composition Lugal, JNES, vol.46, NO.4, 1987.

13- Horowitz, W, The Babylonian Map of The World, Iraq, VOL.50, 1988.

14- http.//www.ETCSL. The Electronic Text Corpus of Sumerian literature.com

15- Jacobsen, Thorkild, Sumerian Mythology ; Areview Article, JNES, VOL. 5, NO.2, 1946.

16- Jensen, P., Mythen Von Zu, dem strmvogel , (Keilinschriftliche Bibliothek -VI), Amsterdam, 1970.

17- King .L. W, Baylonian Religion and Mythology, Vol.IV, London, 1899 .

18- Koeford, A., "Gilgames, Enkidu and the Nether World" (ASJ-5) 1983. 
19- Kramer, S., N. , Enki and his Inferiority Complex, Or- 39, 1970.

$20-$ The Sumerians, University of Chicago, 1963.

21Enki and Ninhursag Aparadise Myth, ANET, New Jers ey ,1969.

22Sumerian Mythology, A study of Spiritual and Literary Achievement in the Third Millennium, DC, New York, 1961 .

23- Leick, G., A Dictionary of Ancient Near Eastern Mythology, London and New York, 1991.

24- Leick, Gwendolyn, Sex And Eroticism In Mesopotamian Literature, London and New York, 1994.

25- Lioyd, Seton, Abu Shahrien; Amemorandum, Iraq, VOL.36, NO.1/2, 1974.

26- Luckenbill, D.D, Historigraphic Documents, 1955.

27- Nejat, K.R.N., Daily life in Ancient Mesoptamia, Hendrickson, 1998.

28- Pritchard, J., Ancient Near Eastern Texts, New Jersey, 1969.

29- Reisman, J, Ninurta's Journey To Eridu, JCS, VOL.24, NO.1/2, 1971

30- Sjöberge, A. Der Montgott Nanna Suen in Der Sumerischen überlifrung, Uppsala, 1961.

31- Sollberger, E., Note on the Early Inscription from Ur and Al-Ubaid, In Iraq, Vol.XXII, 1960.

32- Speiser, E. A., The Myth of Zu ,ANET, New Jersey,1969.

$33-$ The Creation Epic, ANET, New Jersey, 1969.

34- ......................, Aos mological Incantation : the Worm an the Toothache , ANET New Jersey ,1969.

35- Stetkevych. S. P., Structuralist Interpretations of Pre-Islamic Poetry; Critigue and New Directions, JNES, VOL.42, NO.2, 1983.

36- Stol, M, Women In The Ancient Near East, Translated By Helen and Mervyn Richardson, Germany, 2016.

37- Whitley, C. F, The Pattern of Creation in Genesis, Chapter 1, JNES, vol.17, No.1, 1958.

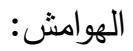

(1) Jacobsen, Thorkild, Sumerian Mythology ; Areview Article, JNES, VOL. 5, NO.2, 1946, p.139.

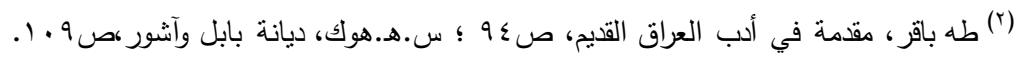

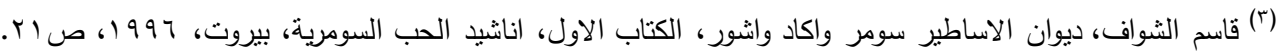

Stol, M, Women In The Ancient Near East, Translated By Helen and Mervyn Richardson, Germany, 2016, p.645.

اكتثف الرقيم الطيني ، الذي دون عليه هذا النص ، في موقع مدينة بابل ، وييدو انه قد اعد ليرتل اثثاء عملية ترميم

المعبد وذلك من اجل احلال البركة وضمان نجاح عملية التزميم. ينظر : نائل حنون، عقائد الحياة والخصب ، صب؟ع.

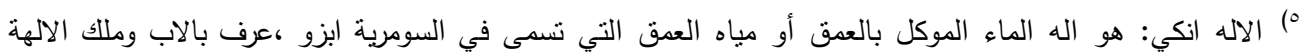

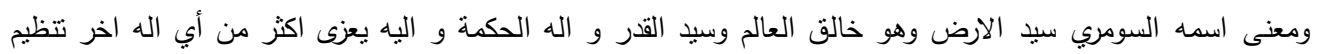


الارض حسب قرارات اينليل الذي كان يضع الخطط العامة اما التقاصيل العملية وتتفيذها فقد نرك ذلك الى الاله انكي المدبر الحكيم و المُجد الماهز و كان يسكن في ابسو (الماء العذب). ينظر: صموئيل نوح كريمر ، من الواح سومر ،

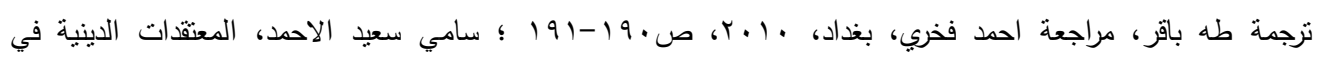

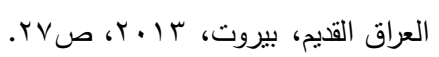

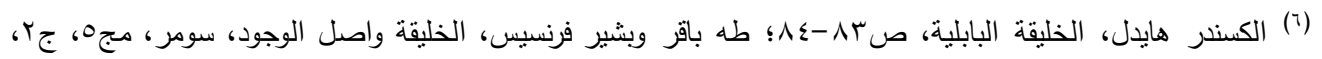

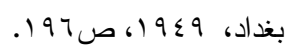

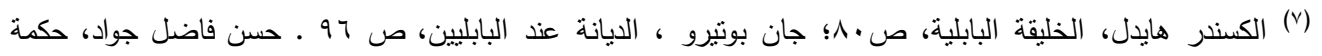

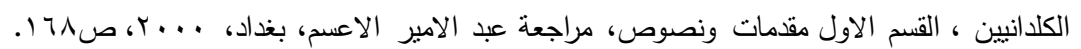
(8) Speiser, E. A., Aosmological Incantation : the Worm an the Toothache , (ANET) 1969 , pp. 100-101.

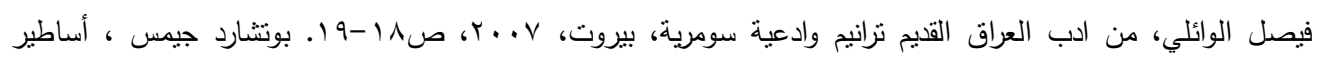

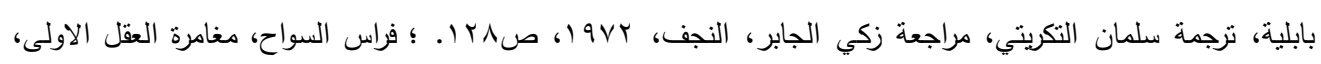

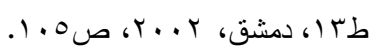

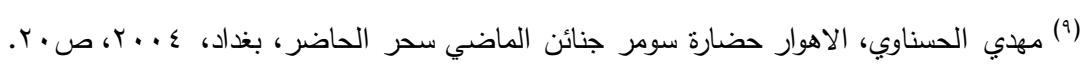

(10) Jacobsen, Thorkild, Sumerian Mythology ; Areview Article, JNES, VOL. 5, NO.2, 1946, p.139.

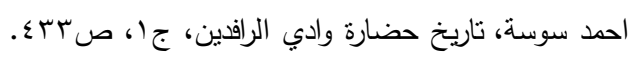

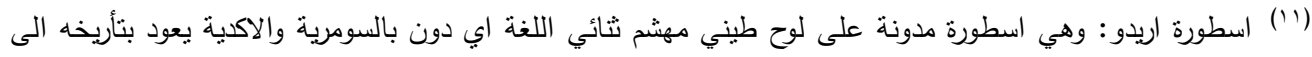

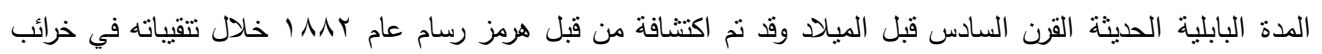
مدينة سبار (ابو حبة) لمزيد من المعلومات حول النص الكامل ينظر : Hidel, A, The Babylonian Genesis, Chicago, 1967, pp.3-61.

- الكسنر هايدل، الخليقة البابلية، ترجمة ثامر مهدي محمد، مراجعة محي الدين اسماعيل، بغداد، ا....،

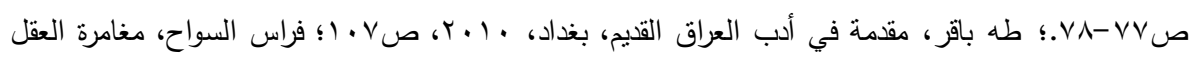

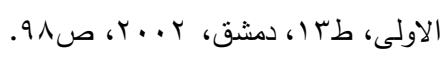

(rا') مدينة أريدو: نقع أطلال هذه المدينة المعروفة اليوم بـ (أبو شهرين )على بعد (•ـ كم) جنوب غرب مدينة الناصرية

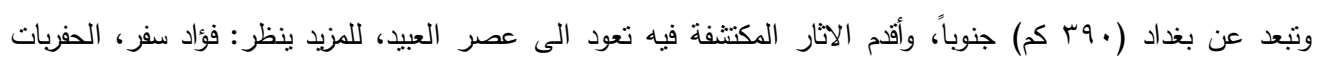

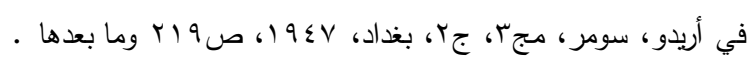

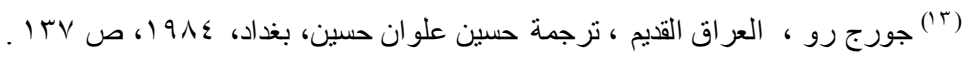




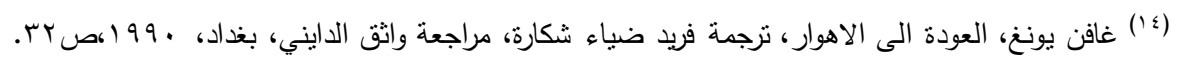

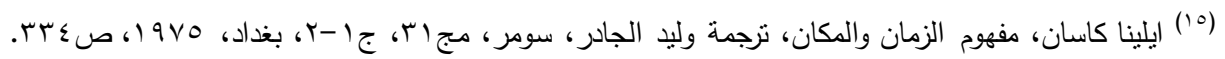

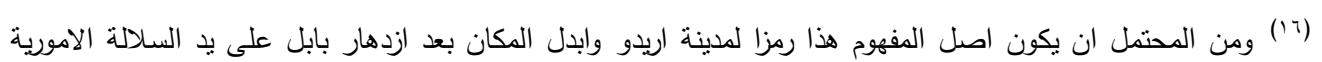

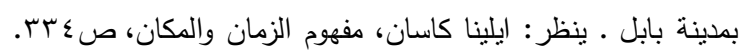

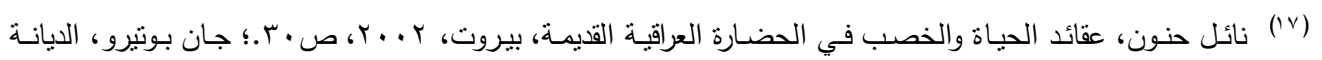

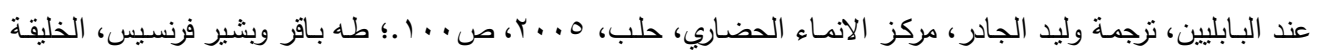

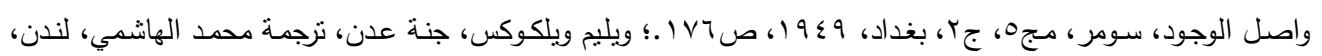

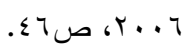

${ }^{(18)}$ Horowitz, W, The Babylonian Map of The World, Iraq, VOL.50, 1988, p.160. - - جفري بارندر، المعتقدات الدينية لدى الشعوب، ترجمة امام عبدالفتاح امام، مراجعة عبدالغفار مكاوي، عالم

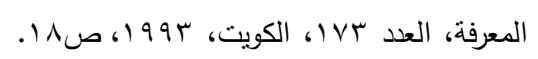

(19) Horowitz, Wayne, Mesopotamian Cosmic Geography, Indiana, 1998, 35.

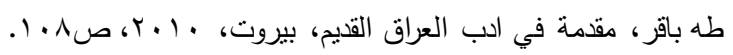

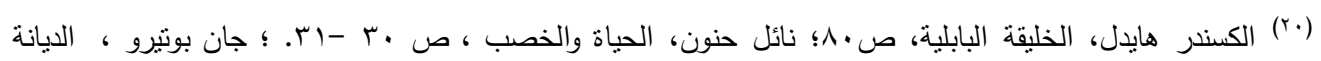

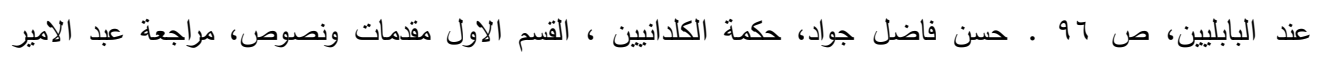

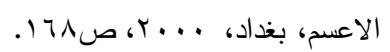

(1) العماء : مصطلح اطلقه أكثر الباحثين في قصة الخليقة البابلية ويعني المادة التي تكونت منها الموجودات وهو شي غامض غير محدود ولا معين تختلط فيه جميع الاشياء • ينظر : طه باقر، ديانة البابليين والاشوريين ، سومر، مج ؟ ب،

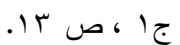

(rr) تيامة: اسمها يعني في اللغة الاكدية ( اليم ) والتي مثلت المياه المالحة "العنصر المؤنث " في قصة الخليقة البابلية ( اينوما ايليش ) ينظر : د. ادزارد و م.هـ.بوب ف. رولينغ، قاموس الالهة والاساطير في بلاد الرافدين (السومرية والبابلية)

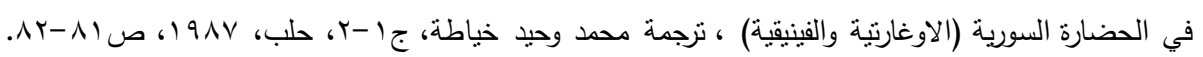
(rr) ابسو : وهي المياه الازلية ( ابسو) المياه العذبة ، مذكر تبامة المياه المالحة ، مؤنث ، ومن امتزاجهما ولد الالهة.

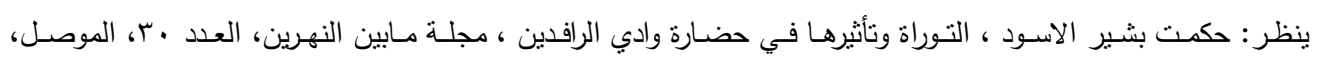
$.1 \leqslant r ص$ ص 191 .

(24) Jacobsen, Thorkild, Sumerian Mythology ; Areview Article, JNES, VOL. 5, NO.2, 1946, p.139;; Whitley, C. F, The Pattern of Creation in Genesis, Chapter 1, JNES, vol.17, no.1, 1958, p.32. 
(ro(roسامي سعيد الأحمد، العراق القديم من العصر الاكدي حتى نهايـة سـلالة بابل الأولى ، المدخل إلى تـاريخ العـالم

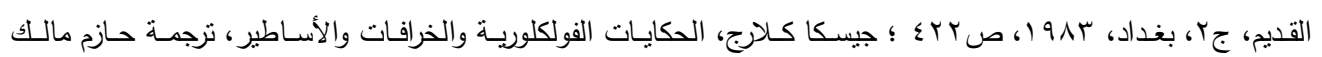

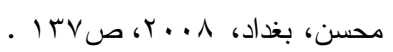

(26) Speiser, E, A, The Creation Epic, ANET, New Jersey, 1969, P.61; Leick, Gwendolyn, Sex And Eroticism In Mesopotamian Literature, London and New York, 1994, p. 15.

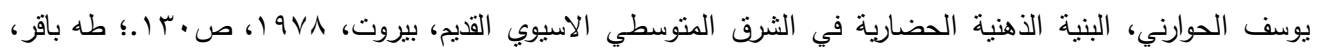

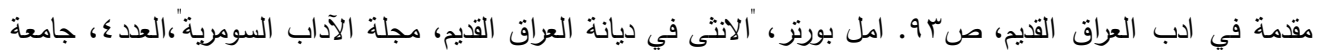

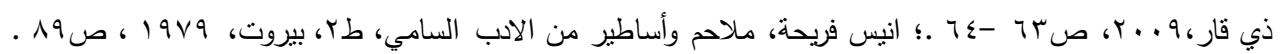

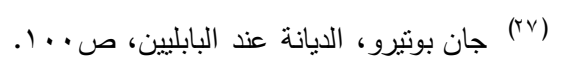

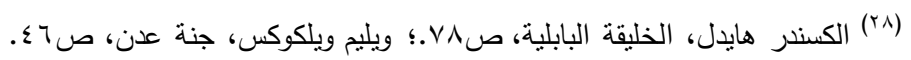

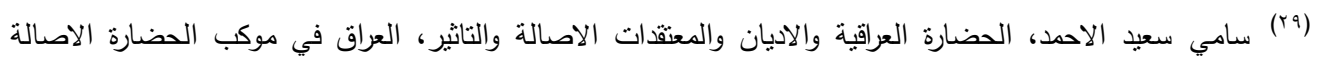

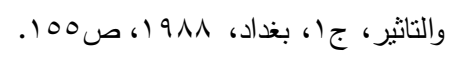

(·r) من الاسماء التي اطلقت على الالهة- الأم بيلٍٍِ - ايلي هو (قرميد اللازورد)، وهذه التسمية مناسبة اذ، ان القرميدة

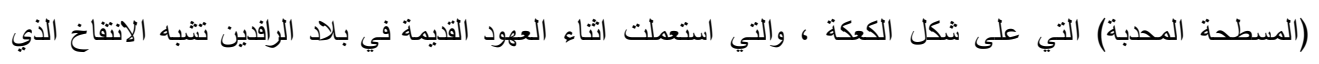

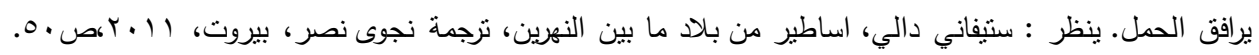

(31) Dalley, S., Myths from Mesopotamia Creation, the Flood, Gilgamesh and Others , Oxford , 1989., p. 16

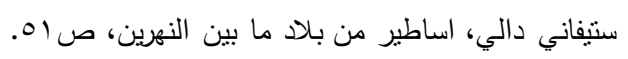

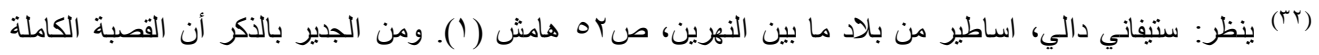

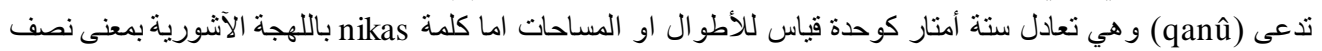

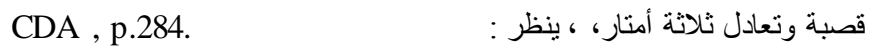

(33) Dalley, S., Myths from Mesopotamia Creation, the Flood, Gilgamesh and Others, Oxford , 1989, p. 17

$$
\begin{aligned}
& \text { ستيفاني دالي، اساطير من بلاد ما بين النهرين، صبه }
\end{aligned}
$$

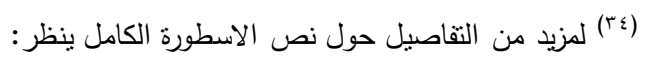

-Jensen, P., "Mythen Von Zu, dem strmvogel" , (Keilinschriftliche Bibliothek -VI), Amsterdam, 1970, pp. 46-53.; Dalley, S. Myths Form Mesopotamia, New York, 1989, pp. 203-227.

(ro) الطائر العملاق انزو: وهو طائر كبير كالنسر له رأس اسد، يوصف بصفات شريرة وقد ظهر على كثير من القطع الفنية منها مسلة العقبان للامير أناتم إذ ظهر فيها كثعار للاله ننكرسو في نهاية شبكته التي يصطاد بها الاعداء. ينظر: 


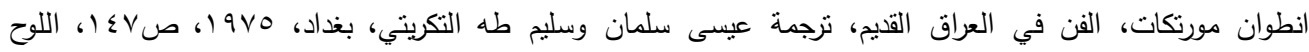

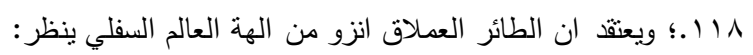

- Fish. T., "The Zu Bird" in the Bulletin of the John Byloands Library. XXXI., 1948, P. $162 \mathrm{ff.}$

(36) Grayson, A, The Myth of Zu, ANET, 1969, pp. 51-49.; Dalley, S. Myths Form Mesopotamia, New York, 1989 ,p207.

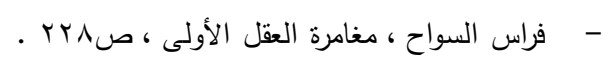

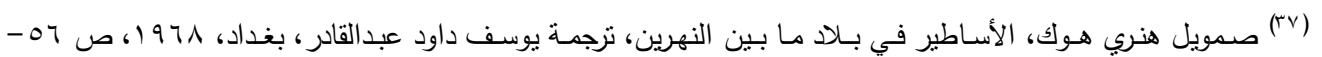

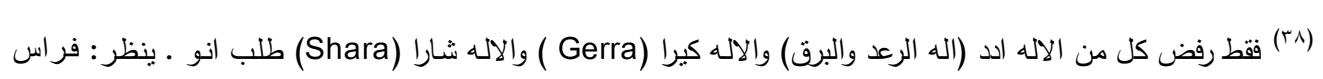

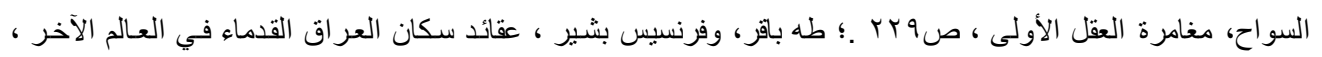

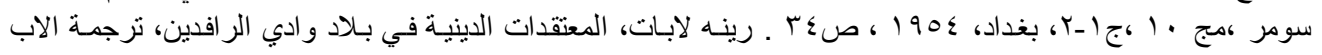

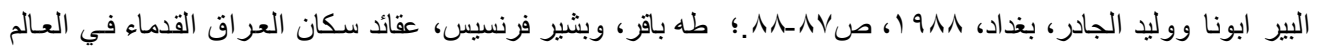

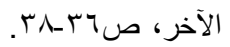

Speiser , E. A., The Myth of Zu , ANET ,p. 111. : Heidel , (BG) , pp. 145-146.

P. Jensen , " Mythen Von Zu, dem Strmvogel ", (KB-VI) , 1970 ,pp. 48-51 ; Dalley, S. Myths Form Mesopotamia, New York, 1989 , pp. 208-210.

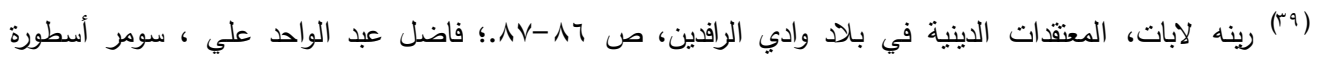

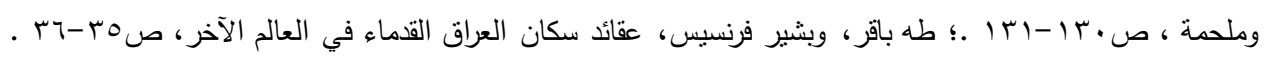
(40) Dalley, S. Myths Form Mesopotamia , pp. 213-214

رينه لابات، المتنقات الدينية في بلاد وادي الرافين، صץو. ؛ فاضل عبدالواحد علي، سومر اسطورة وملحمة، بغداد، . I I I 199V

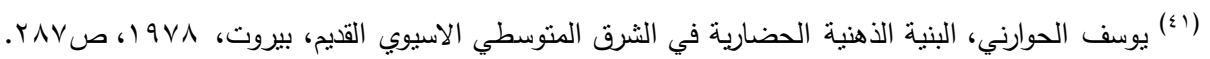

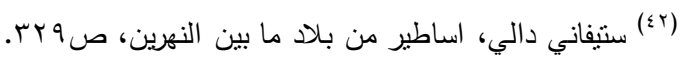

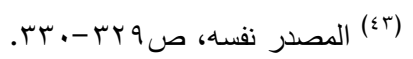

$$
\begin{aligned}
& \text { (؛ ؛وسف الحوارني، البنية الذهنية، صسץ ا. }
\end{aligned}
$$

(45) Grayson, A., The Myth of Zu", ANET , 1969, pp 517-518.

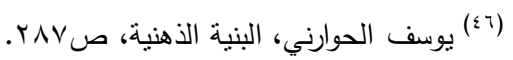

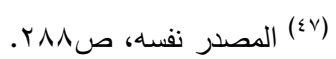

(48) Grayson , A., " The Myth of Zu , pp. 517-518

- - ماضل عبدالواحد علي، سومر اسطورة وملحمة، صسبا. 


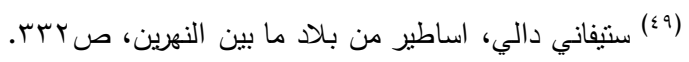

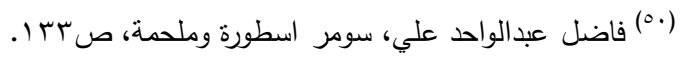

(51) Dalley, S. Myths Form Mesopotamia, pp. 216-218.

فاضل عبدالواحد علي، سومر اسطورة وملحمة، صء؟ ا..؛ فراس السواح، مدخل الى نصوص الثرق القيم، دمثق، .IVE ص r... T

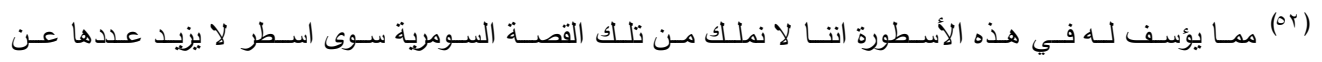

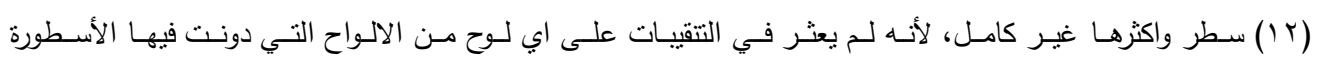

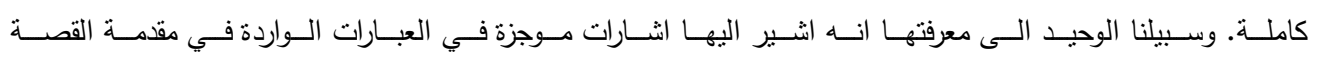

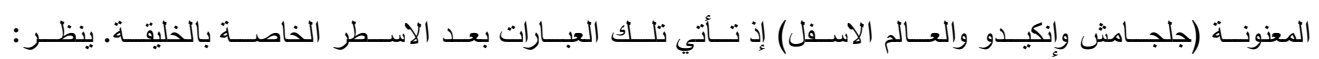

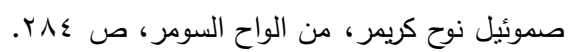

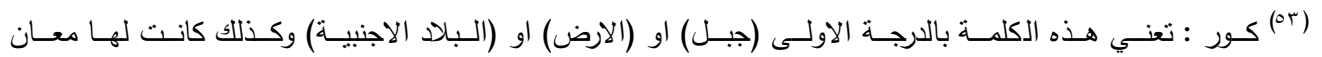

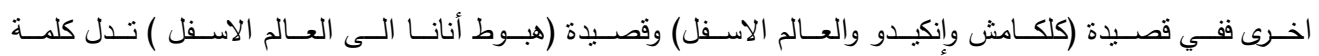

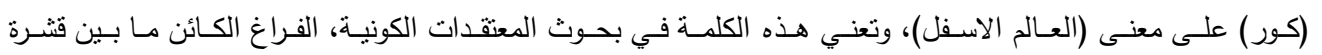

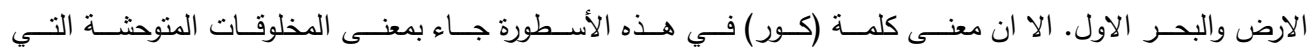

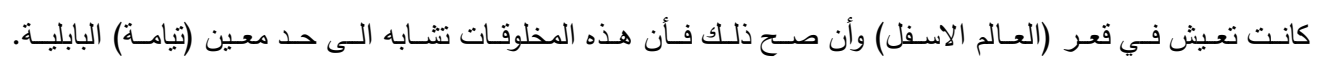

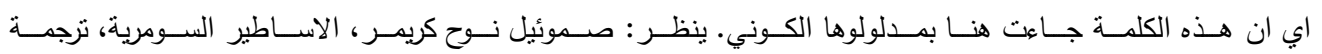

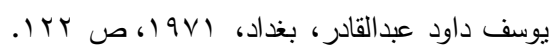

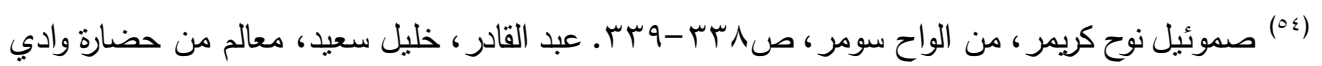

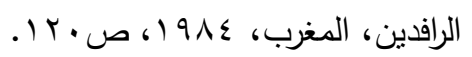

(55) Kramer, S., N. , Enki and his Inferiority Complex, (Or- 39) , 1970, P. 170.; Koeford, A., "Gilgames, Enkidu and the Nether World" (ASJ-5) 1983, p. 17.

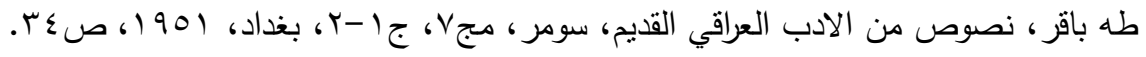
(56) S. N. Kramer, The Sumerians, University of Chicago, 1963, pp. 201-202.

دايان ولكثتاين وصموئيل نوح كريمر ، اينانا ملكة الارض والفردوس اسطورة بلاد ما بين النهرين، ترجمة شاكر

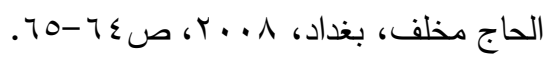
Koeford, A., "Gilgames, Enkidu and the Nether World” (ASJ-5) 1983, p. 17.

(57) Ebeling, J and Cunningham, G, The Electronic Text Corpus of Sumerian Literature, London, 2007, Dumuzid's Dream, NO.213-226. 
صموئيل نوح كريمر، الاساطير السومرية، صVV... قاسم الثواف، ديوان الاساطبر سومر واكاد واشور،

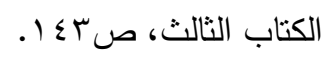

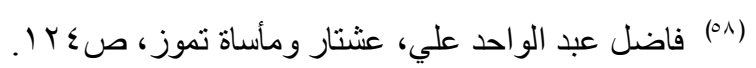

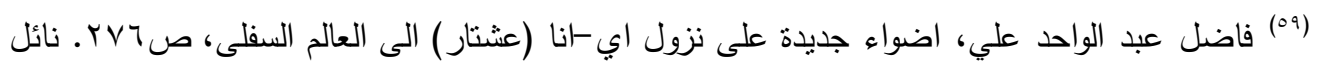

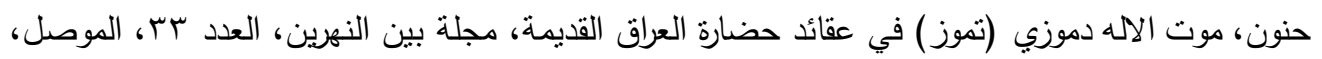

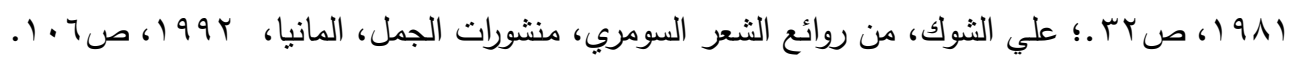

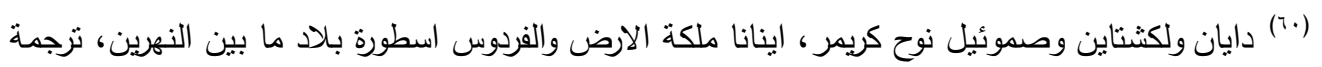

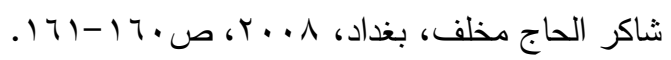

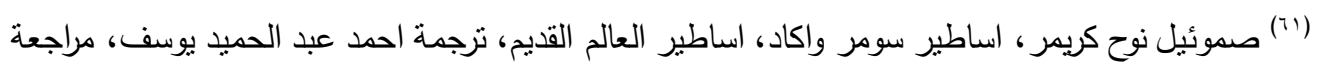

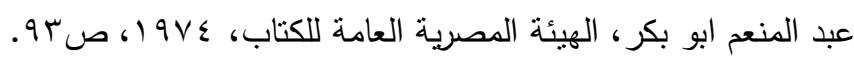
${ }^{(62)}$ Luckenbill, D.D, Historigraphic Documents, 1955, p.302.

(63) Lioyd, Seton, Abu Shahrien; Amemorandum, Iraq, VOL.36, NO.1/2, 1974, p.60.

(64) Ebeling, J and Cunningham, G, The Electronic Text Corpus of Sumerian Literature, London, 2007, Nanna-Suen's Journey To Nibru, NO.37-82.

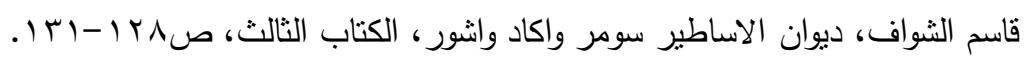

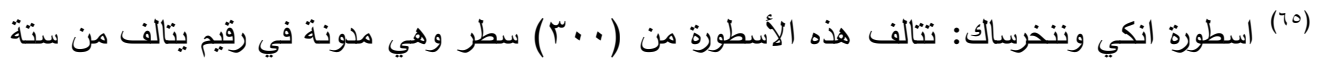

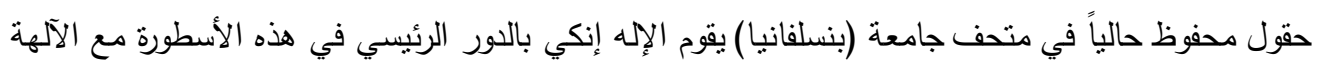

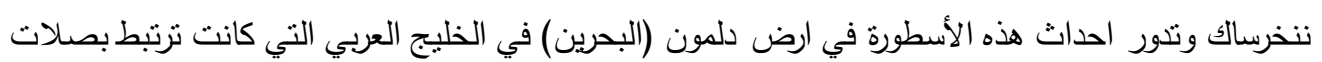

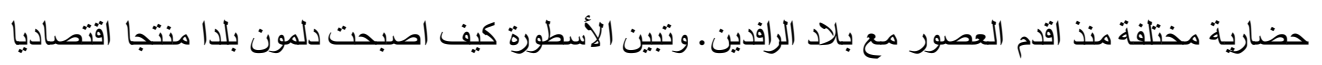

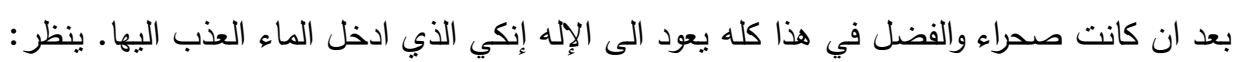
-Leick, G., A Dictionary of Ancient Near Eastern Mythology, London and NewYork, 1991, p.41.؛ Nejat, K.R.N., Daily life in Ancient Mesoptamia, Hendrickson, 1998, p. 183 .

(17) صموئيل نوح كريمر وديان ولكشتاين، الاسطورة السومرية انانا - ارشيكيكال كـيموزي، ترجمة شاكر الحاج

${ }^{(67)}$ King ., Bayloniam Religion and Mythology ,pp. 33-47 .

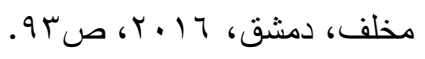

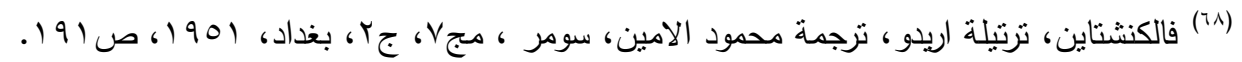

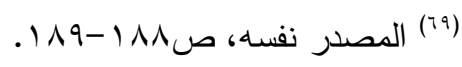


(70) Ebeling, J and Cunningham, G, The Electronic Text Corpus of Sumerian Literature, London, 2007, Nanna-Suen's Journey To Nibru, NO.176-185.

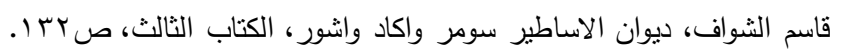

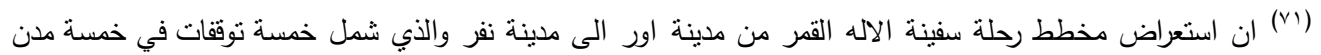

يعطي الدليل غير المباشر على وجود طريق تجارة نهري محلي ربما استعمل من قبل السفن التجارية وقتذاك ينظر :

- Lioyd, Seton, Abu Shahrien; Amemorandum, Iraq, VOL.36, NO.1/2, 1974, p.60.

(72) Leck, G. A Dictionary of Ancient Near Eastern Mythology, p.126.

$$
\text { صموئيل نوح كريمر، الاساطير السومرية، صه. }
$$

(73) Al - Fouadi, A. Enki Journey to Nippur the Journey of the Gods, London, 1969, pp. 27 28.

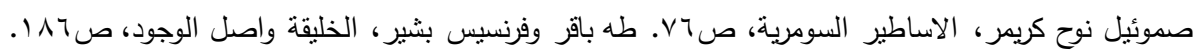

(74) Ebeling, J and Cunningham, G, The Electronic Text Corpus of Sumerian Literature, London, 2007, Nanna-Suen's Journey To Nibru, NO.284-293.

$$
\text { قاسم الثواف، ديوان الاساطير سومر واكاد واشور ، الكتاب الثالث، ص. •ـ ا. }
$$

(75) Ebeling, J and Cunningham, G, The Electronic Text Corpus of Sumerian Literature, London, 2007, Enki and Ninmah, NO.44-51.

(Uttu) الهة النسيج من ضمن الالهة التي ورد ذكر ولادتها في اسطورة أنكي وننخرساك وهي بنت

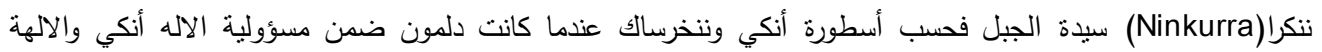

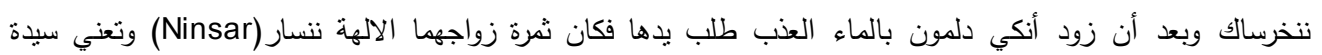

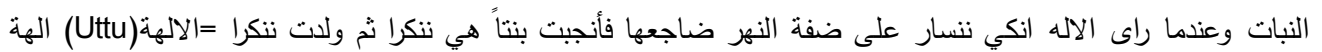

Kramer,S,N,"Enki and Ninhursag Aparadise Myth" ANET, p.37. النسيج. بيظر:

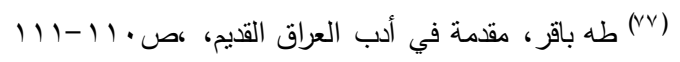

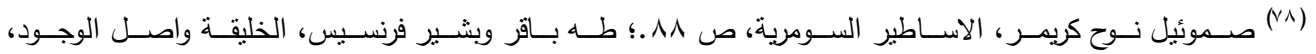

Bottero, J., Every Day life in Ancient Mesopotamia, translated by Antonia Nevil, Creat Britain, 2001, PP. 18-20.

(v9) عثر على هذا النص في مدينة نفر ويتالف من (1 Yq) سطراً يعود تاريخ تدوينه الى نهاية الالف الثالث قبل الميلاد

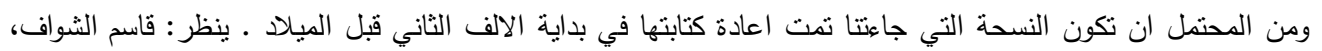

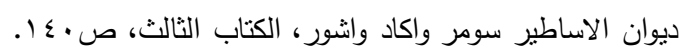

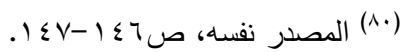

(اكتثف الرقيم الطيني ، الذي دون عليه هذا النص ، في موقع مدينة بابل ، وييدو انه قد اعد ليرتل اثثاء عملية ترميم

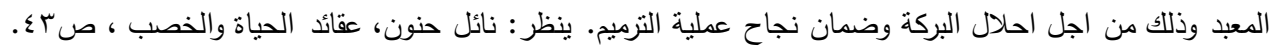


(Ar) الاله انكي: هو اله الماء الموكل بالعمق أو مياه العق التي تسمى في السومرية ابزو ،عرف بالاب وملك الالهة

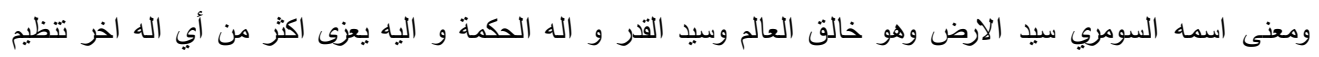

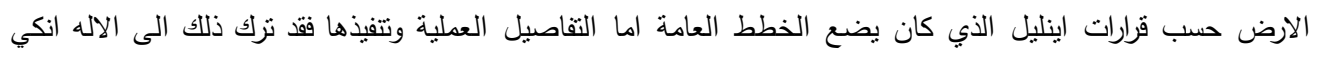

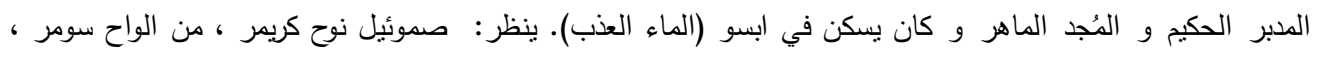

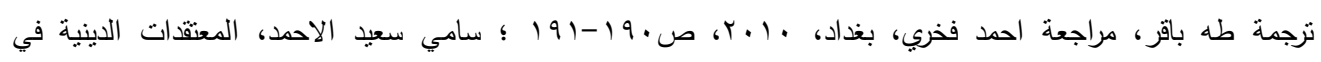

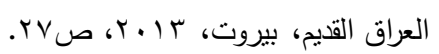

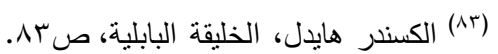

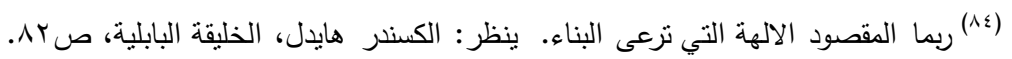

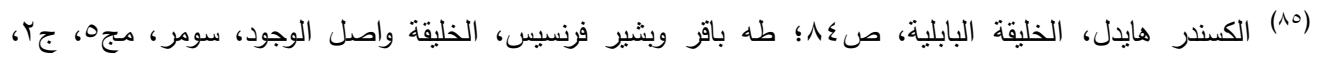

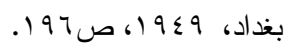

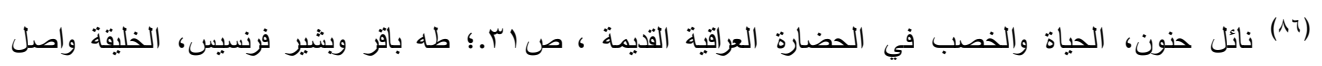

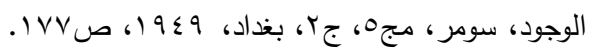

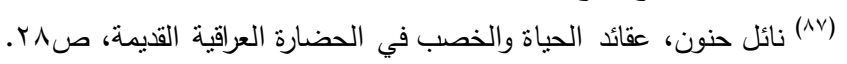

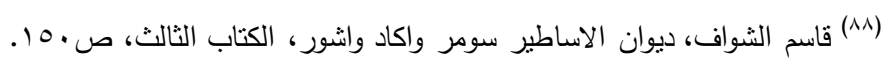

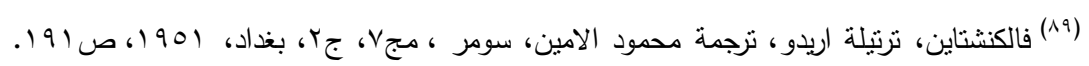

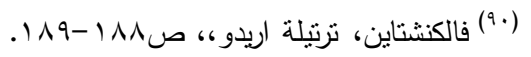

Ebeling, J and Cunningham, G, The Electronic Text Corpus of Sumerian Literature, London, 2007, Enki's Journey to Nibru, NO.83-92.

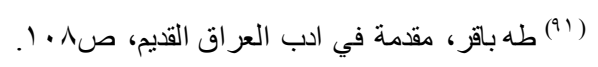

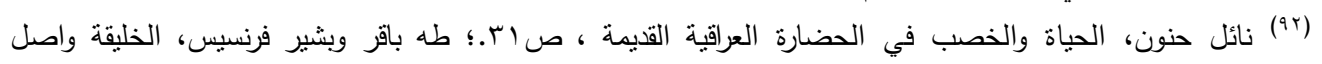

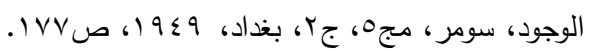

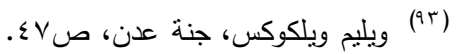

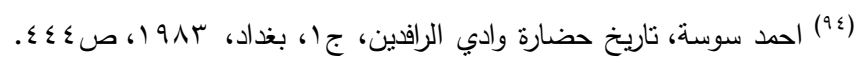

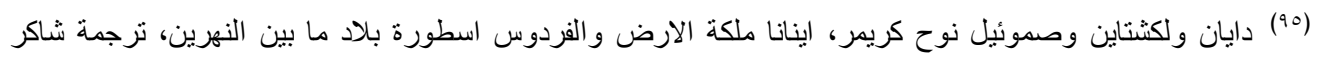

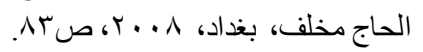

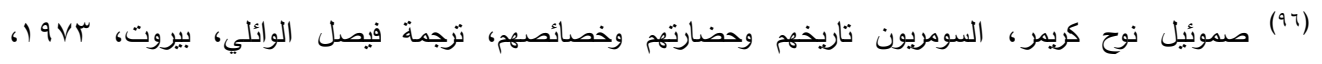

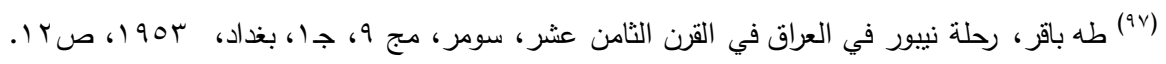

(98) CAD, Vol-A/ I), p. 56.80

(99) Ebeling, J and Cunningham, G, The Electronic Text Corpus of Sumerian Literature London, 2007, Ninurta's Exploits; Asir-Šud To Ninurta, NO. 581-591.

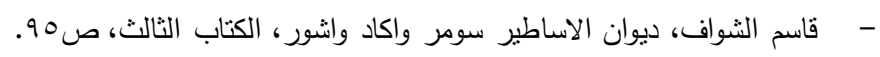


(..') وردت هذه المواجهة في الاسطورة المعنونة (ننورتا يخضع شعب الحجارة) وتتالف من 17 رقيم تصف ثورة الجبل

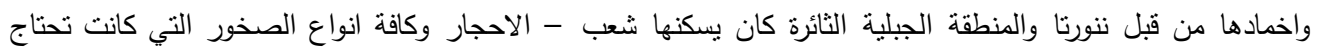

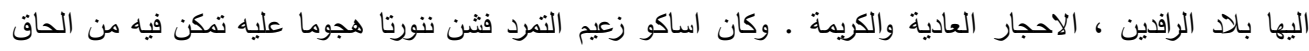

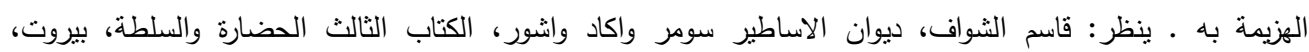

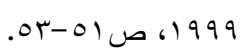

فيما يشير الاستاذ جاكوبسن ان سبب الحرب هي ان الاسطورة تصور الاله ننورتا ملكاً شاباً محارباً يعلم ان منافساً قد نشأ

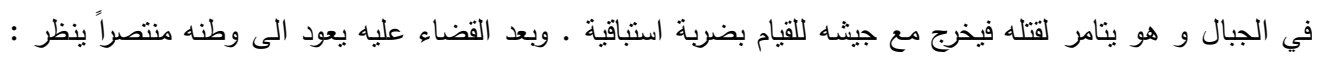

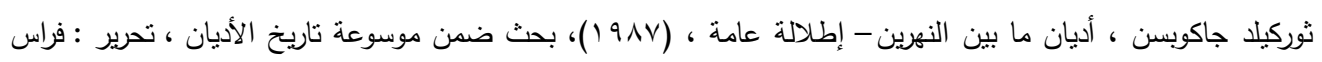

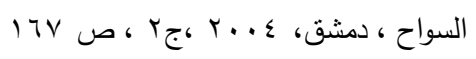

(101) Heimpel, Wolfgang, The Natural History of The Tigris According to The Sumerian Literary Composition Lugal, JNES, vol.46, NO.4, 1987, p.310.

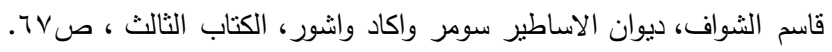

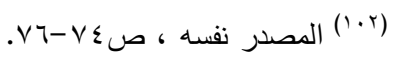

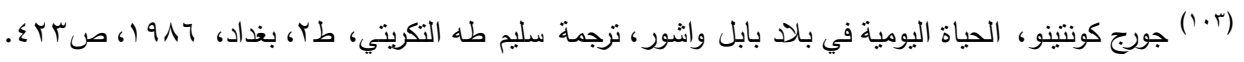

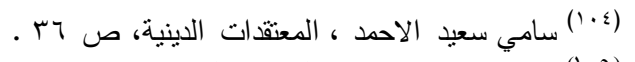

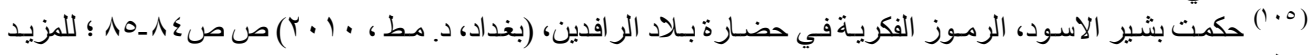

Foster., From distant Days, p.228.

(106) CAD .r . p. 70.

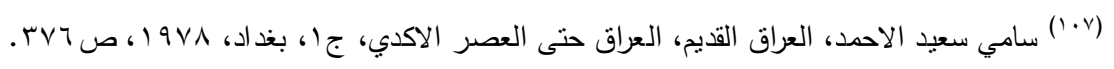

(108) Frankfort, H., King Ship and the Gods, Chicago, 1955, p.37.

$$
\text { فاضل عبدالواحد علي، سومر اسطورة وملحمة، ص191. }
$$

${ }^{(109)}$ Ferrara, A. J. Nanna Suen`s Journey to Nippur, Rome, 1973 , pp. 49 - 50.

Sjöberge, A. Der Montgott Nanna Suen in Der Sumerischen überlifrung, Uppsala, 1961, pp.164-165.

$$
\begin{aligned}
& \text { فاضل عبدالواحد علي، سومر اسطورة وملحمة، ص99. } 99 .
\end{aligned}
$$

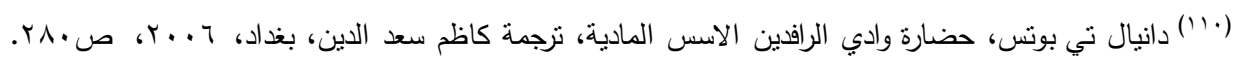

Kramer. Sumerian Mythology, pp.47-48.

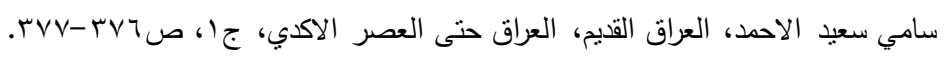

(111) Ebeling, J and Cunningham, G, The Electronic Text Corpus of Sumerian Literature, London, 2007, Nanna-Suen's Journey To Nibru, NO.331-339.

صموئيل نوح كريمر، الاساطير السومرية، صVV.؛ قاسم الثواف، ديوان الاساطير سومر واكاد وانشور، الكتاب الثالث، ص ص إن 


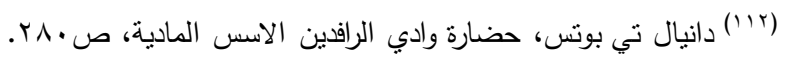

Kramer. Sumerian Mythology, pp.47-48.

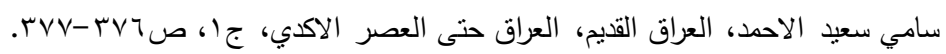

(113) Reisman, J, Ninurta's Journey To Eridu, JCS, VOL.24, NO.1/2, 1971, p.5.

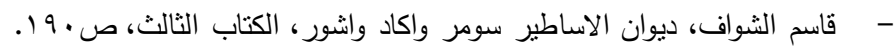

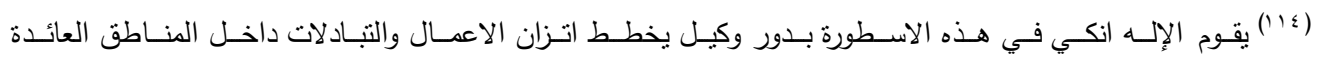

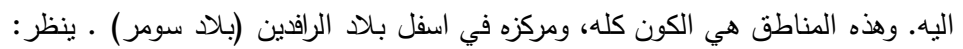

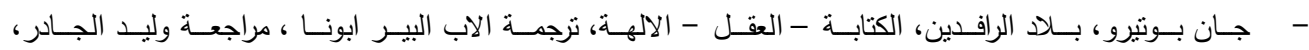

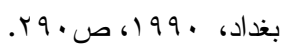

Frankfort, H., and others, The Intellectual Adventure of Ancient Man, Chicago, 1946, pp. 160-161.

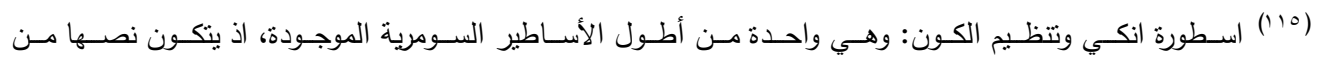

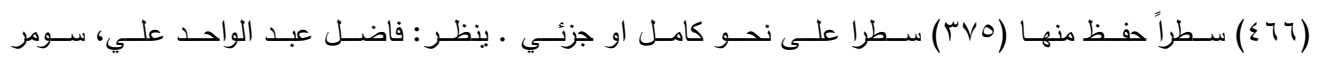

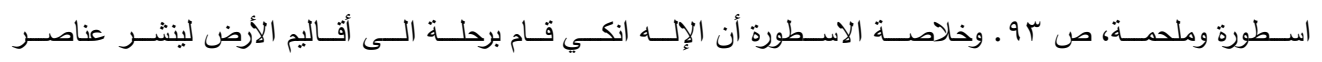

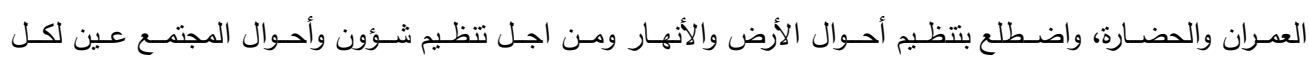

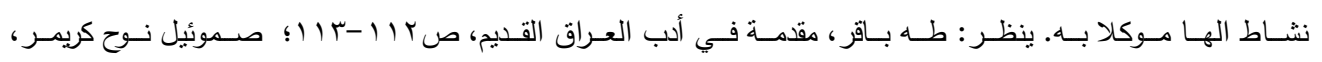

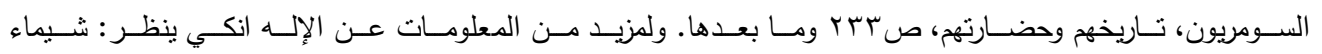

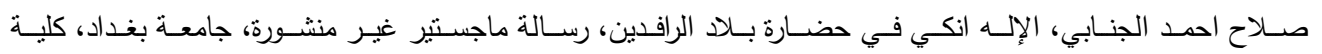

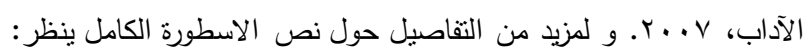

-http.//www.ETCSL. The Electronic Text Corpus of Sumerian literature.com

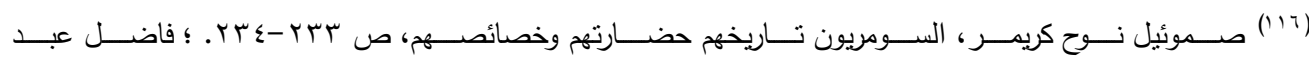

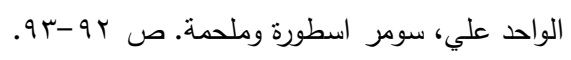

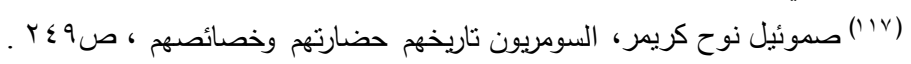

-Sollberger, E., "Note on the Early Inscription from Ur and Al-Ubaid", In Iraq, Vol.XXII, 1960, P.70.

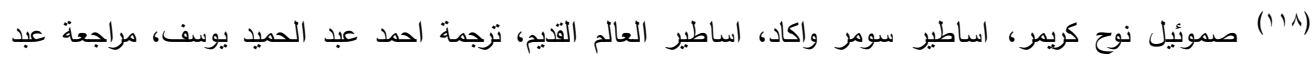

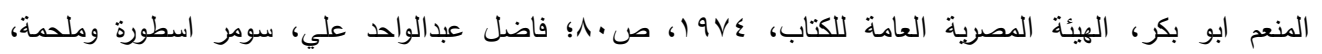

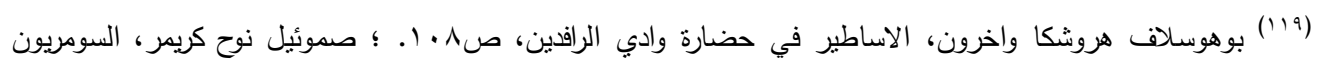

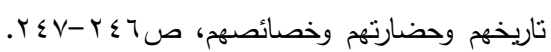

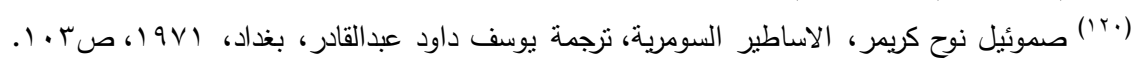




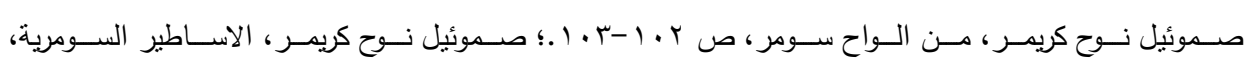

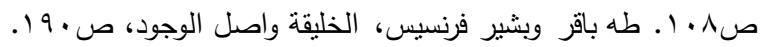

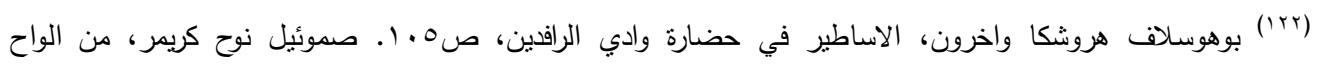

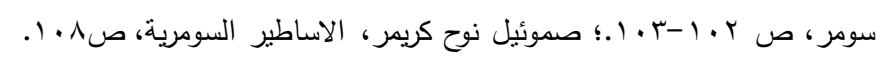

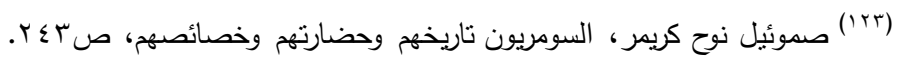

(124) Pritchard, J., Ancient Near Eastern Texts, New Jersey, 1969, pp.38-40.. Ebeling, J and Cunningham, G, The Electronic Text Corpus of Sumerian Literature, London, 2007, Enki and Ninhursaga, NO.63-68.

(125) Dickson, Keith, Enki and Ninhursag; The Trickster in Paradise, JNES, VOL.66, NO.1, 2007, p.7.; Leick, Gwendolyn, Sex And Eroticism In Mesopotamian Literature, London and New York, 1994, p.32.

(126) Stetkevych. S. P. , Structuralist Interpretations of Pre-Islamic Poetry; Critigue and New Directions, JNES, VOL.42, NO.2, 1983, p.105.

صموئيل نوح كريمز ،الأساطير السومرية ،صوب .ـ؛ قاسم الشواف، ديوان الاساطير سومر واكاد وانشور، الكتاب الاول،

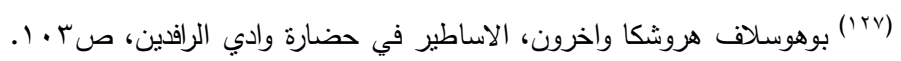

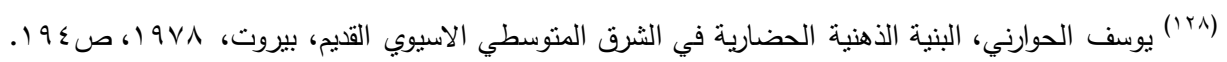

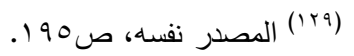

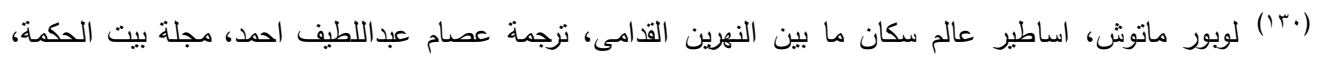

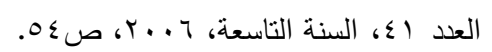

(IT) بوهوسلاف هروشكا واخرون، الاساطبير في حضارة وادي الرافين، نرجمة عصام عبد اللطبف احمد، بغداد،

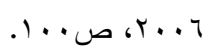

Ebeling, J and Cunningham, G, The Electronic Text Corpus of Sumerian Literature, London, 2007, Enki and The World Order, NO.89-99.

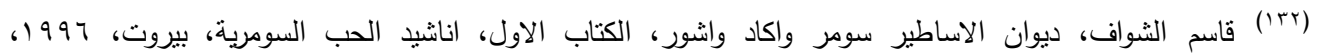

